\title{
Organic matter characterization and distribution in sediments of the terminal lobes of the Congo deep-sea fan: Evidence for the direct influence of the Congo River
}

\author{
Stetten Elsa 1, 2, ", Baudin Francois ${ }^{1}$, Reyss Jean-Louis ${ }^{3}$, Martinez Philippe ${ }^{4}$, Charlier Karine ${ }^{4}$, \\ Schnyder Johann ${ }^{5,6}$, Rabouille Christophe ${ }^{3}$, Dennielou Bernard ${ }^{7}$, Coston-Guarini Jennifer ${ }^{8}$, \\ Pruski Audrey M. ${ }^{2,9}$
}

1 Univ Paris 06, Univ Paris 04, Inst Sci Terre Paris ISTeP, CNRS, F-75005 Paris, France.

2 Univ Paris 06, Univ Paris 04, Stn Marine Banyuls Mer, Observ Oceanol,LECOB,UMR 8222, F-66650

Banyuls Sur Mer, France.

${ }^{3}$ Domaine CNRS, Lab Sci Climat \& Environm, CEA CNRS UVSQ IPSL UMR 8212, F-91198 Gif Sur

Yvette, France.

4 Univ Bordeaux 1, Environm \& Paleoenvironm Ocean \& Continentaux, CNRS UMR C 5805, F-33405

Talence, France.

5 Univ Paris 06, Univ Paris 04, ISTeP, UMR 7193, F-75005 Paris, France.

${ }^{6}$ CNRS, UMR 7193, ISTeP, F-75005 Paris, France.

7 IFREMER, UR Geosci Marines, F-29280 Plouzane, France.

8 Univ Bretagne Occidentale, UMR LEMAR 6539, IUEM, F-29280 Plouzane, France.

9 CNRS, UMR 8222, Lab Ecogeochim Environm Benth, F-66650 Banyuls Sur Mer, France.

* Corresponding author : Elsa Stetten, email address : elsa.stetten@gmail.com

\begin{abstract}
The terminal lobe complex of the Congo River submarine fan sits on the abyssal Atlantic plain, at $5000 \mathrm{~m}$ water depth, $760 \mathrm{~km}$ offshore from the river mouth estuarine area. While most rivers deliver particulate material to the continental shelf, particulate matter from the Congo River largely bypasses the shelf and is transported by turbidity currents through the Congo submarine canyon system. We determined the quantity and quality of the organic matter reaching the terminal lobe complex at five sites with marked morphological differences that may influence the distribution of organic matter. A suite of bulk geochemical (\% OC, $\delta 13$ Corg, $\delta 15 \mathrm{~N}, \mathrm{C}: \mathrm{N}), 137 \mathrm{Cs}$ and palynofacies analyses were done on cores collected from the terminal lobe area. These results were also compared to the composition of sediments collected upstream at the Malebo Pool (Congo River).
\end{abstract}

Distal lobe complex sediments contain high amounts of terrestrial organic carbon (3-5 wt.\%) that is homogeneously distributed in surficial $(22 \mathrm{~cm})$ and deeper sediments $(580 \mathrm{~cm})$ silty-clay facies. Strongly altered soil-derived organic matter with well-preserved land plant detritus from the Congo River predominates. A terrestrial soil origin for the particulate load was confirmed by the elevated 137Cs activity in lobe sediments. The vertical distribution of the 137Cs signal suggests that there has been a massive arrival of terrestrial sediments since 1963, consistent with a turbiditic origin. From the locations surveyed, 
we estimate a maximum accumulation of terrestrial organic carbon of ca. $1 \mathrm{~kg} \mathrm{OC} \mathrm{m-2} \mathrm{y-} 1$ for the distal lobe. However, transport modifies the organic matter both in terms of quantity and quality. Observed differences were attributed to preferential degradation of nitrogenous matter during diagenesis and to the addition of highly remineralized marine organic matter.

Results from our temporal reference site (E) suggest that organic matter may be preserved in turbidite facies for thousands of years. The good preservation state of the accumulated organic matter shows that turbiditic lobe complexes should be considered as a sink for terrestrial organic carbon in the deep ocean.

\section{Graphical abstract}

Relationship between stable isotopes of nitrogen and carbon measured on OM in all the cores analyzed $(n=94)$ in the overall recent and abandoned lobe complexes. The majority of points are tightly clustered and associated with the deep sea fan environment; these have isotopic signatures typical of C3 plants. Each box is constructed with data from different sources. Congo River data are from Mariotti et al. (1991) and Spencer et al. (2012). "Active zone" illustrates the recent lobe complex where turbiditic inputs dominate (data from this study and Baudin et al., 2010). "Abandoned zone" illustrates the northern lobe complex and other parts of the Congo deep sea fan where pelagic inputs dominate (data from this study and Holmes et al., 1996; Müller et al., 1994; Schefuss et al., 2004). Marine POM data are from Tyson (1995), Meyers (1997), Fischer et al. (1998) and Schefuss et al. (2004).

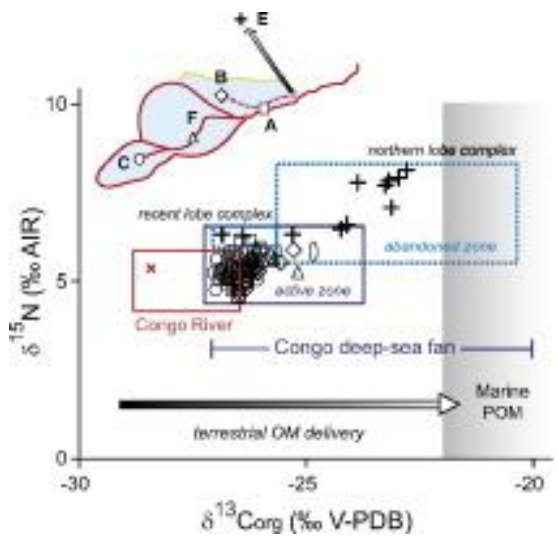

\section{Highlights}

Lobe complex and Congo River sediments have similar geochemical characteristics. Concentration of soil-derived organic carbon is high in lobe sediments. Turbiditic deposition explains the geochemical homogeneity of lobe sediments. ${ }^{137} \mathrm{Cs}$ reveals recent and substantial turbiditic deposition in the lobe complex. The lobe complex represents a huge sink for terrestrial organic carbon.

Keywords: Congo River, Turbiditic system, Recent lobe complex, Terrestrial organic matter, Preservation 
Acknowledgements

We would like to thank G. J. De Lange, editor in chief of Marine Geology and three anonymous reviewers for their constructive comments. We are indebted to Ifremer/Genavir, captains (Gilles Ferrand and crews) for the sampling campaigns WACS and CONGOLOBE onboard the R/V Pourquoi Pas? We are grateful to Florence Savignac for her analytical help and Alexandre Lethiers for participation in drawings. We also acknowledge Sabrina Lucas, 
Gilles Vétion and Solveig Bourgeois for their participation in sampling during WACS and Congolobe legs. B. Bombled and P. Noel were responsible of the Multicore sampling and L. Droz and B. Dennielou of the piston core sampling during Congolobe and WACS respectively. We also thank Rob Spencer and Helen Talbot for providing samples from the Congo River. This work was supported by the ANR grant Congolobe (ANR-11-BS56-0030, 2011-2016) and is a contribution to Ifremer project "Biodiversité et fonctionnement des écosystèmes profonds, impacts”. Elsa Stetten was supported by a doctoral fellowship from the French Ministry of Research and Education. 


\section{Introduction}

Quantities of terrestrial organic carbon (OC) exported by the world's major rivers to the ocean are estimated at between 200 to 500 Tg. $\mathrm{y}^{-1}$ (Meybeck, 1993, Schlünz and Schneider, 2000, Cai, 2011 and Galy et al., 2015). Despite substantial efforts devoted to monitoring this flux and producing estimates of contributions to the global carbon budget, many important aspects of the fate of this carbon remain unexplored. For example, once terrestrial organic matter (OM) reaches the ocean, it undergoes dynamic, biogeochemical processes during transport, sedimentation, and burial in deep-sea environments (Hedges et al., 1997 and Blair and Aller, 2012) which are only partially understood. In general, terrestrial OM exported to the oceans is considered more refractory than marine $\mathrm{OM}$ and thus terrestrial $\mathrm{OM}$ is expected to be better preserved in marine sediments than marine OM (Hedges and Keil, 1995 and Burdige, 2007). Yet, preferential preservation of terrestrial OM could also be explained by several factors either alone or in combination, such as: its molecular composition (ligno-cellulosic polymers), the complex geomacromolecules formed during humification which are strongly associated to the mineral matrix (Hedges and Oades, 1997), and the depositional system dynamics 
(sedimentation rate, sediment exhumation) at a particular coastal zone interface (Mc Kee et al., 2004).

The Congo deep-sea fan provides an opportunity to examine how an unusually rapid transfer of terrestrial OC to the deep-sea affects the processes of accumulation and preservation. Other major rivers (e.g. the Amazon, Yellow or Mississippi rivers) deposit their sediments predominantly on the continental shelf (Walsh and Nittrouer, 2009), however, the Congo River sediments mostly bypass the shelf environment. Instead, the Congo submarine canyon, which incises the shelf as far back as $30 \mathrm{~km}$ into the estuary (Savoye et al., 2000 and Babonneau et al., 2002), funnels river sediments to the base of the continental slope and the abyssal plain via turbidity currents where they accumulate on the Congo deep-sea fan. The fan itself is composed of intricate stacks of channel-levee structures built-up on the seafloor through multiple progradation, retrogradation and switching phases. The geologically active channel-levee system extends $800 \mathrm{~km}$ off the river mouth (Droz et al., 2003) and at its distal extremity it forms a geomorphological feature called the "distal or terminal lobe".

This region is considered the ultimate depositional zone for particulate materials originating upstream in the canyon and transported by turbidity currents along the Congo deep-sea turbiditic channel (Savoye et al., 2000 and Babonneau et al., 2010). Turbidity currents have been detected by submarine cable breaks since the late $19^{\text {th }}$ century (Heezen et al., 1964) and monitored at $4000 \mathrm{~m}$ water depth, $500 \mathrm{~km}$ off the Congo River mouth (Khripounoff et al., 2003 and Vangriesheim et al., 2009). Presently, sedimentation rates calculated from ${ }^{210} \mathrm{~Pb}$ are qualified as high on the lobe complex (1.9 cm. $\mathrm{y}^{-1}$; Rabouille et al., 2009). Until now, one preliminary survey reported a high OC content that was attributed to terrestrial inputs from the Congo River $\left(\mathrm{OC}=3.45 \%, \mathrm{C}: \mathrm{N}_{(\text {molar }}=16.1\right.$; Rabouille et al., 2009). From these data, the lobe complex is considered as the main terminal and depositional center for sediment from the Congo River (Rabouille et al., 2009 and Vangriesheim et al., 2009). The Congo River is the 
second largest exporter of terrestrial OC in the world after the Amazon (Richey et al., 1980 and Coynel et al., 2005). The annual export of OC to the Congo estuary and the equatorial Atlantic Ocean reaches 14.4Tg among which $2 \mathrm{Tg}$ are particulate organic carbon (POC) (Coynel et al., 2005). The fine POC fraction ( $<63 \mu \mathrm{m},>80 \%$ of the total suspended load) is derived from strongly leached soils, but the coarse POC fraction is from well-preserved, modern, higher vascular plants and is dominated by a C3 signature (Mariotti et al., 1991 and Spencer et al., 2012). Marine OM also is deposited on the deep-sea fan from the extremely productive coastal and pelagic systems (Berger, 1989 and Wenzhöfer and Glud, 2002). This production is stimulated by oceanic and coastal upwelling and nutrients delivered from the Congo River plume (Holmes et al., 1996, Schefuss et al., 2004 and references therein). One goal of the French Congolobe project is to better characterize OM deposited at the extremity of the recent turbiditic channel of the Congo deep-sea fan (Fig. 1a and 1b) to understand the functioning of benthic ecosystems observed during the BioZaïre program (Sibuet and Vangriesheim, 2009). The present paper describes new results from a series of cores in the fan's terminal lobe complex and addresses the contribution and quality of sedimentary OM found there. We also reconsider here the fate of OM sedimentation in abyssal plains and turbiditic environments, and the decadal to millennial timescales on which terrestrial OM could be trapped and preserved in deep ocean environments.

2. Hydrological, geological and biogeochemical settings

The Congo River is the second largest river in the world in terms of catchment area $\left(3.710^{6}\right.$ $\mathrm{km}^{2}$ ) and water discharge $\left(41000 \mathrm{~m}^{3} . \mathrm{s}^{-1}\right.$ in average; Laraque et al., 2001). Its tributaries cross the equatorial zone resulting in a very stable intra-annual flow regime and discharge compared to other large rivers like the Amazon (Coynel et al., 2005 and Laraque et al., 2013). The river has a very low annual sediment discharge $\left(5.510^{7} \mathrm{t}\right.$; Wetzel, 1993) that is attributed to the low overall altitude of the Congo watershed, the presence of numerous lakes and 
floodplains, strongly leached ferralitic soils and the extensive vegetation cover (Laraque and Olivry, 1996 and Seyler et al., 2004). The river drains evergreen forests surrounded by savannah for $50 \%$ of its total watershed area, and then stretches for more than $1000 \mathrm{~km}$ on the "Cuvette Congolaise" where swampland and forests are inundated during the wet season (Coynel et al., 2005). At about $450 \mathrm{~km}$ upstream of its estuarine system, the Congo River broadens into a hydrological feature called the Malebo Pool (Kinshasa/Brazzaville - Fig. 1c), where its flow lessens considerably. Because the POC at this location and the river mouth shows little geochemical difference, the Malebo Pool is treated as a reference site for the characteristics of the OM delivered by the Congo River to the ocean (Spencer et al., 2012).

The Congo deep-sea fan is located on the Congo-Angola margin in the southern Atlantic Ocean, and is one of the largest submarine fans in the world. It extends nearly $1000 \mathrm{~km}$ offshore the African coast with an estimated area of $330000 \mathrm{~km}^{2}$ and a volume of $0.7 \times 10^{6}$ $\mathrm{km}^{3}$ (Savoye et al., 2000 and Droz et al., 2003). The initiation of the fan dates from the Oligocene (Savoye et al., 2000) and it is composed of three major submarine fan structures, of which the axial fan is the most recent (Savoye et al., 2009). During the ZAIANGO 1 and 2 surveys, $200000 \mathrm{~km}^{2}$ of this structure were mapped and stratigraphic correlations suggested that the axial fan could date from the Quaternary (Savoye et al., 2000). The Late Quaternary portion of the fan is composed of more than 80 channel-levees (Droz et al., 2003). This fan is fed by turbiditic flows passing through the submarine canyon, and prolonged by the active channel which extends for about $800 \mathrm{~km}$ offshore and descends down to $5100 \mathrm{~m}$ depth, ending in a distal lobe complex (Fig. 1a and 1b; Babonneau et al., 2002 and Droz et al., 2003). This active channel is characterized by a well-pronounced sinuous channel-levee morphology which tends to vanish at the extremity where it spreads into the amalgamated lobe-shaped deposits called the lobe complex (Savoye et al., 2000, Savoye et al., 2009, Babonneau et al., 2002 and Babonneau et al., 2010). In this area, hemipelagic sedimentation 
rates are low at the base slope and on the abyssal plain they are reported to be less than $c a .3$ cm.ka ${ }^{-1}$ (Jansen et al., 1984). Sedimentation rates are higher along the active levees and increase downstream, from ca. $50 \mathrm{~cm} . \mathrm{ka}^{-1}$ in the upper fan to $c a .450 \mathrm{~cm} . \mathrm{ka}^{-1}$ at the entrance to the lobe complex (Savoye et al., 2009).

The recent lobe complex (Fig. 1b.) is organized into 5 lobes (Babonneau, 2002), from the oldest (1) to the youngest (5). The chronological hierarchy is based on the prograding and migrating pattern visible in the lobe complex which shows that lobes have developed successively westward from the turbiditic channel (Fig. 1b). Channel depth is less than $10 \mathrm{~m}$ and decreases downstream. Another lobe complex with a similar pattern occurs about $20 \mathrm{~km}$ to the north and is referred to here as the "northern lobe complex" (Fig. 1b). The northern lobe complex was fed by a channel that is now disconnected from the actual active channel, $85 \mathrm{~km}$ upstream of the entry of the recent lobe complex. The geometry of the channel suggests that the northern lobe complex is older than the recent lobe complex and was abandoned after the recent turbiditic channel bifurcated to the south to build the recent lobe complex (Babonneau, 2002). The age of these two lobe complexes is still a matter of debate but a gross estimation for the age of the turbiditic levees upstream of the lobe complexes suggests an Holocene age (ca. $7 \mathrm{ka}$ ) for the onset of the recent lobe complex (and therefore the abandonment of the northern lobe complex), and a Last Glacial Maximum age ( $c a .20 \mathrm{ka}$ ) for the onset of the northern lobe complex (Dennielou, 2002 and Babonneau, 2002).

3. Materials and methods

\subsection{Coring sites}

To investigate the spatial distribution and the evolution of OM, sediment cores were collected from an upstream-downstream transect on different geomorphological features (Fig. 1b, Table 1). Sites A, F and C are located along the active channel. Site A is located between the entry points of lobes 2 and 3, site $\mathrm{F}$ is located $15 \mathrm{~km}$ upstream of the entry of lobe 5 , site $\mathrm{C}$ is 
located in the lobe 5 at the termination of the active channel (Fig. 1b). At site A, the channellevee structure is more pronounced than at sites F and C. Site B is located at the termination of the channel feeding the lobe 3 . Site $\mathrm{E}$ is located on the northern lobe complex. Based on the geology, site B is disconnected from the functioning channel but probably receives material during important turbiditic events (Savoye et al., 2000, Babonneau, 2002, Dennielou, 2002 and Bonnel, 2005). Site $\mathrm{E}$ is disconnected from the active system and is believed to be abandoned; it has not received turbiditic sediment during the Holocene ( $c a .7 \mathrm{ka}$ ). Considering this geomorphological configuration, we have designated sites A, F, C, and B as the "active zone" because they are located close to the active channel, and site E-the "abandoned zone". In addition, three sites were sampled for ${ }^{137} \mathrm{Cs}$ at the Malebo Pool (details in Talbot et al., 2014) for comparison with the deep-sea sediments.

\subsection{Sampling strategy}

For this study, 9 short sediment cores (labelled MTB) of $\sim 22 \mathrm{~cm}$ long $(\varnothing 9.5 \mathrm{~cm})$ were collected using a multicorer MUC 8/100 (Oktopus GmbH), (Table 1). Two short cores were collected during the WACS survey (February 2011) and the other cores were collected during the Congolobe survey (December 2011-January 2012). Sediment short cores were sliced (0$0.5 \mathrm{~cm} ; 0.5-1 \mathrm{~cm} ; 1-2 \mathrm{~cm} ; 2-3 \mathrm{~cm} ; 3-5 \mathrm{~cm} ; 5-7 \mathrm{~cm} ; 7-10 \mathrm{~cm} ; 10-13 \mathrm{~cm} ; 13-16 \mathrm{~cm} ; 16-19 \mathrm{~cm}$; 19-22 cm) and stored at $-80{ }^{\circ} \mathrm{C}$ for elemental and isotopic analyses or at $4{ }^{\circ} \mathrm{C}$ for palynofacies analysis. Six other MTB cores from the same sites on the lobe complex were sampled for ${ }^{137} \mathrm{Cs}$ (details on these samples are in supplementary data table). A single $910 \mathrm{~cm}$-long Calypso piston core (Kullenberg-type, labelled CS) was recovered inside the channel at site C. We identified turbidite horizons by counting silty-clay intervals. Samples from this core were used for elemental, stable isotopes and ${ }^{137} \mathrm{Cs}$ analyses.

3.3. Porosity and grain size analysis 
The porosity $(\phi)$ of sediment was determined from the water loss after freeze-drying preweighed aliquots of homogenized sediment and assuming a value of $1.05 \mathrm{~g} . \mathrm{cm}^{-3}$ for pore water density (representative for most of deep water sediment below $4000 \mathrm{~m}$ ) and $2.76 \mathrm{~g} . \mathrm{cm}^{-3}$ for the grain density, (deep-sea fan terrigenous sediments, Hamilton, 1976). Porosity has been determined only for the sediment sampled during Congolobe cruise. Grain size analyses were done using a laser granulometer (Malvern Instruments, Mastersizer 2000). Prior to analysis, carbonates were removed with dilute $(10 \%) \mathrm{HCl}$. To prevent flocculation of clay particles, sediment aliquots were placed in a solution of dispersing agent (sodium hexametaphosphate $\left(\mathrm{NaPO}_{3}\right)_{6}$ at $5.5{\mathrm{~g} . \mathrm{l}^{-1}}^{-1}$ for $24 \mathrm{~h}$ on a rotating platform. Just before analysis, samples were treated by ultrasound for 10 seconds (adapted from the protocol described by Sperazza et al. (2004)).

\subsection{Carbon and nitrogen analysis}

Total carbon content was measured with a precision of $0.1 \%$ on dried sediments using a high temperature combustion method (LECO IR 212 with an induction furnace HF-100, LECO Corporation). The carbonate content was estimated using either Rock-Eval pyrolysis (Vinci Technologies; analytical precision of $\pm 0.12 \%$ ) or a carbonate-bomb method (Müller and Gastner, 1971) which has an analytical precision of $\pm 0.2 \%$ (content $<6 \%$ wt, Baudin et al., 2010, and this study, data not shown). Organic carbon content (\% OC) was obtained by subtracting the carbonate content from the total carbon content, assuming that calcite and aragonite were the only forms of inorganic carbon in the sediment.

$\mathrm{C}: \mathrm{N}$ atomic ratios, and stable isotope compositions of carbon and nitrogen were determined by on-line combustion of subsamples from the short cores $(n=77)$ and from the long piston core $(n=16)$ in a Carlo Erba NC 2500 instrument connected to an Isoprime isotope ratio mass spectrometer. All samples were pre-treated with $1 \mathrm{~N} \mathrm{HCl}$ to remove inorganic carbon. C:N 
atomic ratios were obtained from the samples total organic carbon (TOC) and nitrogen (N). The ${ }^{13} \mathrm{C} /{ }^{12} \mathrm{C}$ and ${ }^{15} \mathrm{~N} /{ }^{14} \mathrm{~N}$ ratios are expressed using the conventional $\delta$ notation in parts per thousand relative to the values measured in the PeeDee Belemnite (PDB) for carbon and in the atmosphere for nitrogen. Analytical precisions are $\pm 0.15 \%$ for $\delta^{13} C_{\text {org }}$ and $\pm 0.2 \%$ for $\delta^{15} \mathrm{~N}$ relative to an internal standard.

On the piston core samples, a nitrogen analysis was also done of the bulk sediment. The linear relationship $\left(\mathrm{R}^{2}>0.9 ; \mathrm{p}<0.05\right)$ between TOC and N and a near zero intercept $(y=0.07 \mathrm{x}-$ 0.01) indicates that all the nitrogen is associated with OC. The average relative standard deviation (determined by replicate measurements of each sample) was $\pm 5 \%$.

Weighted means were calculated for each parameter described above to take into account differences in weight between each horizon; these could vary by a factor of 10 between subsurface samples and deeper samples. There are very good correlations between the weighted and the arithmetic means for each parameter $\left(\mathrm{R}^{2}>0.9, \%\right.$ OC values, $\delta{ }^{13} \mathrm{C}, \delta^{15} \mathrm{~N}$, and $\mathrm{C}: \mathrm{N}, \mathrm{p}<0.05)$. All data are provided in the supplementary dataset.

\subsection{Palynofacies determinations}

Palynofacies were determined for 18 samples that were selected based on granulometry and geochemical results (cores COL-A-MTB-2, COL-A-MTB-3, COL-C-MTB-10 and COL-EMTB-14). This method relies on visual inspection of all the particulate OM present in a sediment sample after leaching of carbonates and silicates by $\mathrm{HCl}-\mathrm{HF}$ treatment (Tyson, 1995). The residues were sieved (> $10 \mu \mathrm{m})$ and then mounted on standard glass microscope slides. The relative amounts of each of four organic particle categories in the field of view were determined. The analysis was done with an Axioskop 40 microscope (Zeiss). Different possible palynomorph categories are presented in Table 2 .

\section{6. ${ }^{137} \mathrm{Cs}$ measurement}


The activity of ${ }^{137} \mathrm{Cs}$ was measured as described in Rabouille et al. (2009) on 2-4 g of dried sediment (Legeleux et al., 1994). Briefly, counting was done using three high-efficiency, lowbackground Well-type Ge detectors (active volumes were 215, 430 and $980 \mathrm{~cm}^{3}$ ). All measurements were done at the Laboratoire Souterrain de Modane (France) which specializes in this type of analysis (Reyss et al., 1995). IAEA standards were used to calibrate the detectors: RGU-1, RGTh-1 and an artificial sediment standard (U and Th standards from the NIST). The analytical precision is $0.2 \mathrm{~Bq} . \mathrm{kg}_{-}{ }^{1}$ relative to this standard.

\section{Results}

The principal downcore changes from the short cores of all five sites are illustrated in Figures

\section{2, 3, 4 and Table 3.}

4. 1. Characteristics of the deposits at the sediment interface (sites A, F, C and B), recent lobe complex

Despite being collected in various morpho-sedimentary environments, sediments from the recent lobe complex (sites A, F, C and B) all show relatively similar sedimentological properties, compositions and distributions (Fig. 2, Table 3). Each site is characterized by a high OC content $(2.9 \%-3.9 \%)$, highly negative $\delta^{13} \mathrm{C}_{\mathrm{org}}$ values of around $-26.5 \%$, $\delta^{15} \mathrm{~N}$ values around $5 \%$, and high C:N values $(15.4-18.5)$. Contribution of fine silty-clay sediment is around $80 \%$ with clays (particles $<4 \mu \mathrm{m}$ ) contributing for $\sim 20 \%$ in each core. The median grain size is around $10 \mu \mathrm{m}$. Cores from sites A, B and the WACS-C-MTB-04 from site C-channel show little variations in sediment properties with some horizons more rich in very fine to fine sand. Cores COL-C-MTB-06 and COL-C-MTB-10, from site C, have the most homogeneous grain size distribution. No significant correlations between the physical and geochemical properties measured have been found except for the $\mathrm{C}: \mathrm{N}$ ratio that is positively correlated with the median grain size $\left(\mathrm{R}^{2}=0.3, \mathrm{p}<0.05, \mathrm{n}=90\right)$, negatively 
correlated with the porosity $\left(\mathrm{R}^{2}=0.5, \mathrm{p}<0.05, \mathrm{n}=60\right)$ and with clay content $\left(\mathrm{R}^{2}=0.2, \mathrm{p}<0.05\right.$, $\mathrm{n}=90)$.

The core COL-A-MTB-2 is presented in this study to illustrate the visual aspect of the OM in sediments from the recent lobe complex (Fig. 4). There is a change in palynofacies characteristics with depth in this core. Surface samples (horizon $0.5-1 \mathrm{~cm}$ is quite similar to horizon 0-0.5 and 1-2 cm) are dominated by orange color amorphous organic matter (AOM). Deeper in the core, the amount of AOM decreases as the quantity of well-preserved terrestrial fragments increases. Well-preserved translucent plant fragments dominate. Ligno-cellulosic debris may present discernible vegetal fiber or cells. In general, each sample analyzed shows orange to grey AOM in different proportions with well-preserved higher plant fragments of various sizes depending on the sites and horizon.

${ }^{137} \mathrm{Cs}$ activities measured at site $\mathrm{A}$ and $\mathrm{C}$ on channel and levee are between $0.7 \mathrm{~Bq} . \mathrm{kg}^{-1}$ and 2.5 Bq. $\mathrm{kg}^{-1}$ (Supplementary data). The profiles (Fig. 3) show that ${ }^{137} \mathrm{Cs}$ activities vary within the sediment column with no clear tendency to diminish and the depth of ${ }^{137} \mathrm{Cs}$ disappearance has not been reached in these cores. At site $\mathrm{B}$, the ${ }^{137} \mathrm{Cs}$ activities are similar in the top ten centimetres of the core (between 1.2 and $1.8 \mathrm{~Bq} . \mathrm{kg}^{-1}$ ), then activity diminishes drastically below $10 \mathrm{~cm}$ depth to $0 \mathrm{~Bq} . \mathrm{kg}^{-1}$ at around $15 \mathrm{~cm}$ depth.

\section{2. Site $E$}

On the northern lobe complex, geochemical properties (\% OC, $\left.\delta^{13} \mathrm{C}_{\mathrm{org}}, \delta^{15} \mathrm{~N}, \mathrm{C}: \mathrm{N}\right)($ Fig. 2 , Table 3) of sediments (core COL-E-MTB-14) show striking differences with sediments from the recent lobe complex. The grain size fluctuates little with clay content (ranging from $18 \%$ to $30 \%$ and a mean grain-size of $7.2 \mu \mathrm{m}$ ). For other parameters, two contrasting intervals are identified (Fig. 2, Fig. 4). The top 7 centimetres are characterized by a lower \% OC (around $0.7 \%$ ), lower C:N ratios (around 11.4), higher $\delta^{13} \mathrm{C}_{\mathrm{org}}$ and $\delta^{15} \mathrm{~N}$ values (about $-23.3 \%$ and 
$7.9 \%$, respectively). In contrast, from $7 \mathrm{~cm}$ to $22 \mathrm{~cm}$, sediments have a much higher OC content (2.0\%), higher C:N ratios (14), and lower $\delta^{13} \mathrm{C}_{\text {org }}$ and $\delta^{15} \mathrm{~N}$ values (around $-25.4 \%$ and $6.4 \%$ respectively). These results are consistent with the visual observations of a gradual transition in the palynofacies (Fig. 4). In the top ten centimetres, grey, poorly preserved AOM and marine palynomorphs predominate, while some terrestrial palynomorphs are also present. Below this horizon, AOM becomes orange-colored indicating better preservation with depth and the terrestrial palynomorphs appear very similar with those observed in sediments from the recent sites (Fig. 4, COL-A-MTB-2). These results suggest that organic material at the base of core COL-E-MTB-14 has similar characteristics to that of sediments from the recent sites. Finally, the ${ }^{137} \mathrm{Cs}$ activity at site $\mathrm{E}$ is extremely low and close to the limit of detection (Fig. 3).

\section{4. Long core (COL-C-CS-06) at site C}

The visual description of core COL-C-CS-06 is detailed in the figure 5 caption. Briefly, we identified two large deposition modalities. The observation indicates the presence of 12 accumulated and undisturbed turbidites $(0-170 \mathrm{~cm})$. Each turbidite is composed of fine grain sediments (clay to silty-clay) enriched in plant debris, becoming finer toward the top. Between $170 \mathrm{~cm}$ to $698 \mathrm{~cm}$ we identified facies probably from an upstream reworking (siltyclay intervals with slump deformation and debrites) and a block of compacted clay with inclined layers at $30^{\circ}$ (interpreted as a transported block). The base of the core (below 750 $\mathrm{cm}$ ) is composed of fine sands with large, visible plant debris. The porosity of the core varies between 0.78 and 0.96 with a mean value of 0.88 for the entire core. The OC content varies between $0.1 \%$ to $4.8 \%$ with a mean value of $3.7 \%$. Below $460 \mathrm{~cm}$, the OC content begins to decrease $(3.7 \%$ to $0.1 \%)$, and the lowest values were measured in the sandy facies at the bottom of the core. In this core, C:N molar ratios and $\delta^{13} \mathrm{C}_{\text {org }}$ varies between 15.2 to 20.2 and $26.5 \%$ to $-24.9 \%$, respectively. This slightly positive isotopic signature is associated with a 
decrease in OC content and in the C:N molar ratio. ${ }^{137} \mathrm{Cs}$ was detected down to $580 \mathrm{~cm}$ (note that the ${ }^{137}$ Cs activity is presented on a logarithmic scale to highlight the activity decrease). Deeper in the core, ${ }^{137} \mathrm{Cs}$ activity is reduced by a factor of about twenty, but is still measurable. Such a reduction may be explained by dilution with fine sand (Fig. 5).

\section{Discussion}

5. 1. Organic carbon content and sources in the recent lobe complex

5. 1. 1. Dominance of terrestrial inputs in the lobe complex

In the recent lobe sediments of the Congo deep-sea fan, the \% OC is an order of magnitude higher than the carbon content measured in Atlantic abyssal seafloor sediments (\% OC generally below $0.3 \%$, rarely exceeding $1 \%$; Mollenhauer et al., 2004). If we adjust for the dominance of the fine POC material $\left(82.7 \%\right.$; 1.15mg. $\left.\mathrm{L}^{-1}\right)$ relative to the coarse POC fraction $\left(17.3 \% ; 0.24 \mathrm{mg} . \mathrm{L}^{-1}\right)$ reported at the Kinshasa-Brazzaville station (Spencer et al., 2012), the adjusted means $-28.5 \%$ for $\delta^{13} \mathrm{C}_{\mathrm{org}}, 5.4 \%$ for $\delta^{15} \mathrm{~N}$ and 13.4 for C:N are very close to values measured in lobe sediments (Table 3). This suggests a considerable amount of terrestrial organic material reaches the distal lobe complex.

Preliminary estimates for the contribution of terrestrial OM were made using a simple twoend member mixing model. We used the value of $-21 \%$ for the marine end member (see the references listed in Figure 6) and the adjusted value of $-28.5 \pm 0.3 \%$ for the terrestrial end member. This method estimates terrestrial contributions on or near the active channel (sites A, F, C and B) of between $70 \pm 3 \%$ (site B) and $79 \pm 3 \%$ (site C channel). These gross estimates are consistent with other values in the literature for the Congo deep-sea fan. For example, Baudin et al. (2010) reported similar values upstream from the distal lobe area for silty-clay sediments deposited along the channel at $4000 \mathrm{~m}$ water depth (Fig. 1a). Our preliminary estimates are also reasonably similar with the composition given for Late Quaternary sediments from ODP site 1075 (located on the northern part of the Congo deep- 
sea fan at $3000 \mathrm{~m}$ ) that are mainly composed of OC rich, terrigenous OM (Holtvoeth et al., 2003).

Nonetheless, these OM contribution estimates can give only a rough indication (and certainly an underestimation) for the relative contribution of terrestrial OM; caveats for this type of estimation have been discussed extensively in earlier studies of this system (Holtvoeth et al., 2003 and Weijers et al., 2009). For example, the definition of a unique end member is problematic because of the heterogeneity of the terrigenous OM delivered by the Congo River (Spencer et al., 2012). The dominance of heavily degraded, soil-derived OM in the deep-sea fan sediments compared to $\mathrm{C} 3$ land plant debris also does not produce a clear estimate of the terrestrial contributions (Holtvoeth et al., 2003 and Weijers et al., 2009). Using a ternary mixing model, Weijers et al. (2009) reported that between the Late Holocene and the Last Glacial Maximum, 38-52 \% of the OC was derived from soil and 21-28 \% of the OC was from land plants, for an OC content from $2.5 \%$ to $3.9 \%$. These values are consistent with our results. Finally, the distribution of $\%$ OC and $\delta^{13} \mathrm{C}_{\mathrm{org}}$ appears to be described well by an exponential curve at the study site (Fig. 6). This is expected if the OC in lobe sediments is from several continental sources that undergo mixing during transport and deposition. 5. 1. 2. What do we know about terrestrial sources present in lobe sediment? Information from earlier studies, indicated that terrestrial OM consists mainly of heavily degraded soil-derived OM in the Congo deep-sea fan sediments (Weijers et al., 2009 and Holtvoeth et al., 2003). Mariotti et al. (1991) suggested that nitrogen-rich humic acid compounds would constitute a large fraction of the total OM transported by the Congo River. AOM generally connotes the presence of marine OM, but it can also indicate the presence of humic terrestrial substances in sediment (Burdige, 2007). Baudin et al. (2010) has classed AOM particles into two subgroups for the active part of the Congo deep-sea fan: first is "fluffy" AOM which could be derived from phytoplankton, while the second appears to have 
a terrestrial origin and is represented by particles with visible remains of phytoclasts. The $\mathrm{AOM}$ in our samples is consistent with both the predominance of degraded soil-derived $\mathrm{OM}$ in the Congo River material and an important contribution by humic substances (Mariotti et al., 1991 and Spencer et al., 2012).

The input of OC from soil is consistent with the ${ }^{137} \mathrm{Cs}$ signal in the cores. In terrestrial environments, cesium adsorbs strongly to clay soil minerals (Hancock et al., 2013). Thus, cesium movement has been treated as dependent on physical processes, and is widely used as a tracer for measuring both soil erosion and sediment accumulation rates (Ritchie and Mc Henry, 1990 and Avery, 1996). In the present study we use ${ }^{137} \mathrm{Cs}$ as a tracer for the Congo River suspended particulate matter. All samples from the Malebo Pool (permanently submerged mud, bank or floodplain of the Congo River) are characterized by high ${ }^{137} \mathrm{Cs}$ activities $\left(2.1 \pm 0.1 \mathrm{~Bq} \cdot \mathrm{kg}^{-1}, 1.6 \pm 0.2 \mathrm{~Bq} \cdot \mathrm{kg}^{-1}\right.$ and $4.0 \pm 0.3 \mathrm{~Bq} \cdot \mathrm{kg}^{-1}$, respectively) and are of the same order of magnitude as those measured in the recent lobe sediments. The contribution of marine ${ }^{137} \mathrm{Cs}$ coming from the overlying surface waters in this oceanic region is low. Given the low ${ }^{137} \mathrm{Cs}$ measured activities measured in Central Atlantic water $\left(1.4 \pm 0.2 \mathrm{mBq} . \mathrm{L}^{-1}, \mathrm{n}=5\right.$; WOMARS, 2005) and considering that it will be exported to the deep ocean along the water column at low sedimentation rates $\left(\sim 0.5\right.$ to $4.4 \mathrm{~cm}$. ky $\left.{ }^{-1}\right)$, we infer that ${ }^{137} \mathrm{Cs}$ marine inputs will be insignificant in lobe sediments with respect to terrestrial inputs. Thus, for the core COL-C-CS-06, the significant positive correlation between $\mathrm{OC}$ and ${ }^{137} \mathrm{Cs}$ activity $\left(\mathrm{R}^{2}=0.5 ; \mathrm{p}<\right.$ $0.05 ; \mathrm{n}=38$ ) suggests a continental source for particles and for OC associated to these particles and suggest that they were transported by the same physical (erosion, transport and deposition) processes to the lobe complex (Kim et al., 2006).

The second OM source that we can characterize is a pool of slightly degraded OM, principally derived from the leaves of tropical C3 plants (Mariotti et al., 1991 and Spencer et al., 2012). According to the literature, particulate OM delivered by the Congo River contains negligible 
contributions from C4 plants (Spencer et al., 2012). Molecular analyses of the particulate organic matter $(\mathrm{POM})$ riverine fractions clearly show $\mathrm{C} 4$ land plants have a limited presence in the bulk terrestrial OM exported by the river to the ocean (Mariotti et al., 1991, Bouillon et al., 2012 and Spencer et al., 2012). On the deep-sea fan, $n$-alkanes from the Congo River have a $\delta^{13} \mathrm{C}$ signature of the $\mathrm{C} 3$ land plants and contribute to the $\delta^{13} \mathrm{C}$ signature of the bulk OM (Schefuss et al., 2004). The many remains of land plants observed in the cores (Fig. 4 and Fig. 5) are consistent with these conclusions.

Another distinct source of OC could be petrogenic carbon (Galy et al., 2015). We cannot highlight this source but the OC petrogenic yield for the Congo River has been reported as $0.01 \mathrm{t} . \mathrm{km}^{-2} \cdot \mathrm{y}^{-1}$ (see supplementary dataset in Galy et al. 2015). If we multiply this value by the catchment area of the Congo River $\left(3.7 \times 10^{6} \mathrm{~km}^{2}\right)$ about $0.04 \mathrm{Tg}$ of the petrogenic carbon is exported by the Congo each year. Thus around $2 \%$ of the exported POC could have a petrogenic signature. Clearly, the Congo River exports mainly biogenic carbon. Fluxes of OC to the sea and burial rates are mainly related to the suspended sediment yield and to physical erosion mechanisms as well as the turbidity currents dynamic. These fluxes depend directly on the amount of primary production within the watershed and the initial compositions of the sources (Spencer et al,, 2012).

5. 2. Organic matter alteration during the transport along the turbiditic channel Even if the Congo River sediments enter rapidly the active channel of the deep-sea fan, biogeochemical processes that can affect this POC during transport should be accounted for. Turbidity currents transport sediments along the meandering, active channel that covers a real distance of $1200 \mathrm{~km}$ from the canyon head to the distal, recent lobe complex (Babonneau et al., 2010). Over this length, it is expected that the initial river load material becomes: (1) degraded, (2) mixed with surrounding sediments containing terrestrial and marine $\mathrm{OM}$ of different age (recent and fresh or aged and altered), (3) mixed with eroded turbiditic material 
from the channel flanks, and (4) deposited upstream from the lobe complex. The significant differences between the Kinshasa-Brazzaville station and our results (\%OC in sediments of the recent lobe complex is 3-4\% lower than in the Kinshasa-Brazzaville station, $\delta^{13} \mathrm{C}_{\text {org }}$ has a signature of about $2 \%$ higher, the $\delta^{15} \mathrm{~N}$ signatures are similar, and C:N ratios are higher) suggest that transport processes along the channel modify the OM both in terms of quantity and quality. As our data $\left(\delta^{13} \mathrm{C}_{\mathrm{org}}, \delta{ }^{15} \mathrm{~N}, \mathrm{C}: \mathrm{N}, \%\right.$ OC) are similar to those obtained for the channel at $4000 \mathrm{~m}$ water depth (Fig. 1a; Baudin et al., 2010) the biogeochemical transformations are occurring over an unknown distance upstream of this depth. Terrestrial C:N values (around 13.4 in this watershed) are largely influenced by the soil derived OM (Spencer et al., 2012); higher C:N ratios in the recent lobe complex and along the turbiditic channel (Baudin et al., 2010; Fig. 1a) could be attributed to preferential degradation of the nitrogen pool from the humic substances during OM diagenesis and/or to the addition of highly remineralized and old marine $\mathrm{OM}$ to the initial terrestrial organic material during the turbiditic transfer (De Lange, 1992, De Lange et al., 1994, Meyers, 1994, Meyers, 1997 and Twichell et al., 2002). This result appears to be very specific to the Congo River deep-sea fan system. For the Congo Angola continental margin (that is outside of the channel region) it was shown that the C:N ratio diminishes with distance from the coast (Müller et al., 1994). In the Gaoping submarine canyon (southwestern Taiwan), where OM is also rapidly transferred to the deep-sea, $\mathrm{C}: \mathrm{N}$ ratios of the particulate $\mathrm{OM}$ diminish and $\delta^{15} \mathrm{~N}$ signatures increase because of the addition of nitrogen-rich marine OM (Selvaraj et al., 2015). The similarity between the $\delta^{15} \mathrm{~N}$ signatures at the Kinshasa-Brazzaville station, recent lobe complex and along the turbiditic channel (Baudin et al., 2010) do not permit any conclusive interpretations about the higher $\mathrm{C}: \mathrm{N}$ ratios. Microbial degradation has been shown to have little influence on the $\delta^{15} \mathrm{~N}$ values of surface sediments from the Congo deep-sea fan (Holmes et al., 1996). 
The increase of $\delta^{13} \mathrm{C}$ between the Congo River particles and the recent lobe complex sediments (Fig. 6) can be accounted for by the addition of marine OM during turbiditic mixing and erosion along the channel. Treignier (2005) identified alcohol biomarkers specific to marine $\mathrm{OM}$ along the active channel and suggested that they originate from the Congo River plume. The river plume is observable up to about $800 \mathrm{~km}$ offshore the estuary and supplies surface communities living in the water column above the channel (Eisma and Kalf, 1984 and van Bennekom and Berger, 1984). Hence, marine OM deposited on the seabed during the quiescence period between turbidity current events could be eroded and mixed in with any terrestrial material in the turbidity flow. Similar processes were invoked to explain the increase of $\delta^{13} \mathrm{C}$ in Pleistocene turbidites from the Amazon turbiditic channel-levee with regard to the $\delta^{13} \mathrm{C}$ of the Amazon River suspended sediment (Goñi, 1997 and Keil et al., 1997).

\section{3. Organic matter deposition and distribution in lobe sediments}

In cores from site A and C, the disappearance depth of ${ }^{137}$ Cs was not reached (Fig. 3). This shows that large amounts of terrestrial sediments were delivered to the recent lobe complex since the first nuclear bombs were tested in 1945 (Zalasiewicz et al., 2014). Such depositions patterns are common to canyon systems were turbidity flows are frequent (eg. Sepik, Nazaré and Fangliao canyons; Walsh and Nittrouer, 2003, van Weering et al., 2002 and Hale et al., 2012).

The homogeneity of the distribution of bulk geochemical parameters measured on short cores (Fig. 2) is related to this pattern of deposition and is especially marked with respect to the OM distribution in clay to silty-clay facies along the Calypso piston core (Fig. 5). The presence of slump, debrite and transported block in the core shows that sediments $(170-698 \mathrm{~cm})$ were previously reworked before being trapped in site $\mathrm{C}$. The presence of ${ }^{137} \mathrm{Cs}$ throughout the 
piston core shows that turbiditic deposition and sediment reworking occurred over a very short time.

Baudin et al. (2010) observed that OM associated with clay and silty-clay sediments is distributed homogeneously on levees that are upstream of the lobe complex. The box labelled "active zone" (Fig. 7) includes values from our study and earlier ones (KZAI cores, Fig. 1a, $\mathrm{n}=49$; Baudin et al., 2010). The overlap in these values is consistent with the hypothesis that the particulate organic material delivered by the Congo River is homogeneously distributed. Turbiditic deposits (characterized by sharp variations in grain size) could also explain the variability in the quality and quantity of OM in cores, as shown in the Ogooué deep-sea turbiditic system (Biscara et al., 2011). However, in the active Congo deep-sea fan area, it is unlikely that the OM distribution in sediments would be controlled by grain size, considering that all sediments cored are already very fine, indicating particle segregation is more important upstream than on the distal lobe.

The box "abandoned zone" (Fig. 7) was constructed by assuming the entire Congo deep-sea fan could be supplied by marine OM coming from the water column (Fig. 7, Müller et al., 1994, Holmes et al., 1996 and Schefuss et al., 2004). Site E straddles these two boxes and the shift in OM characteristics is interpreted as illustrating the transition between turbiditic and marine deposits (Fig. 2, 3 and 7). The marine OM contribution is not exclusive even in the top of the core; the presence of some well-preserved residual land plant phytoclasts (Fig. 4), are evidence that turbiditic processes deliver terrestrial OM to this remote location. Thus, although turbiditic facies are limited to the vicinity of the active channel, it seems that turbidity currents are also able to export sediments to these distant areas, possibly by the dispersion and settling of the upper turbid plume. This supply could also explain the very low activity of ${ }^{137}$ Cs (Fig. 3) in surface sediments of site E.

\section{4. Assessment of terrestrial $\mathrm{OM}$ accumulation rate at site $\mathrm{C}$}


To determine the burial potential for OM entering this environment, both the OM origin and types of depositional processes are accounted for. On the lobe area of the Congo system, inputs are principally due to turbiditic flows (Savoye et al., 2000). The frequency of turbiditic events in the canyon is estimated at about 60 events per century (Heezen et al., 1964). However, these events are not well-described in this area. For example, we cannot yet consider the impact of a particular "starting point" for a turbiditic event and the resuspension of "old" OM that may be transported and redeposited downslope.

Among our localities, site $\mathrm{C}$ located on lobe 1 (Fig. 1b) is considered the most recent lobe at the distal part of the recent lobe complex (Babonneau, 2002 and Bonnel, 2005, section 2). The morphology of this lobe is characterized by turbiditic channel widening together with channel depth shallowing and a decreasing slope (Babonneau, 2002 and Bonnel, 2005). This configuration indicates a decrease in energy for the turbiditic flows favouring the accumulation of fine sediments and other materials mixed in such as plant debris. For example, sediments from the long core sampled at site C (COL-C-CS06) have the highest OC content. Given that the maximum fallout of ${ }^{137}$ Cs dates back to nuclear bomb tests in 1963 (Fig. 5; Cochran, 1985 and Zalasiewicz et al., 2014) a sedimentation rate of $12 \mathrm{~cm} . \mathrm{y}^{-1}$ can be calculated for this core. This sedimentation rate concords with those for other "canyon captured" systems (Walsh and Nittrouer, 2009) and is higher than the previous sedimentation rate determined for the lobe complex $\left(1.9 \mathrm{~cm} . \mathrm{y}^{-1}\right.$, Rabouille et al., 2009).

Using this new value, the $\mathrm{OC}$ accumulation rate on the first $580 \mathrm{~cm}$ of sediments can be calculated using the following formula (Müller and Suess, 1979):

$$
O C_{a c c}=\frac{(O C \times \omega)}{10} \rho_{s e d}(1-\emptyset)
$$

$O C_{a c c}$ corresponds to the $\mathrm{OC}$ accumulation rate $\left(\mathrm{gC} \cdot \mathrm{m}^{-2} \cdot \mathrm{y}^{-1}\right), O C$ to the organic carbon content (wt. \%), $\omega$ to the sedimentation rate $\left(\mathrm{cm} .1000 \mathrm{y}^{-1}\right), \rho_{\text {sed }}$, to the dry sediment density $\left(\mathrm{g} . \mathrm{cm}^{-3}\right)$ 
and $\varnothing$ to the porosity. The OC accumulation rate is estimated as $1550 \pm 200 \mathrm{gOC} \cdot \mathrm{m}^{-2} \cdot \mathrm{y}^{-1}$. Considering that the terrestrial OC contribution for the Calypso core is around $70 \%$ approximately $1 \mathrm{~kg} \cdot \mathrm{m}^{-2} \cdot \mathrm{y}^{-1}$ of terrestrial OM could accumulate annualy in the area of site C. Such a large value has never been reported from the Congo turbiditic system (Mollenhauer et al., 2004 and Rabouille et al., 2009) and is probably related to the particular geomorphological configuration of site C. Site C is situated in a large "gutter" that traps all the fine turbidity particles that reach the extremity of the lobe complex. This result is higher than values calculated for sediments deposited during the last glacial maximum near the active channel-levees systems of the Amazon fans (Schlünz et al., 1999). Indeed, based on this information, only the lobe complex could be qualified as an exceptional sink for terrestrial OC in the deep Atlantic Ocean.

Extrapolating this value to the entire lobe complex would be unrealistic because of the existence of different patterns of deposition inside the present-day lobe complex (Fig. 3). However, this region is an important OC burial site for the Atlantic Ocean. For comparison, in recent lobe complex sediments the POC deposition rate was estimated at around $0.2 \mathrm{~kg}$ OC.m ${ }^{2} \cdot y^{-1}$ (Rabouille et al., 2009). Scaling up to the total area of the lobe complex $\left(3000 \mathrm{~km}^{2}\right.$, Savoye et al., 2000), Rabouille et al. (2009) suggested that the recent lobe complex could receive $0.7 \mathrm{Tg} . \mathrm{y}^{-1}$ of POC, of which $0.4 \mathrm{Tg} \cdot \mathrm{y}^{-1}$ may be buried. In comparison with the quantity of POC delivered by the Congo River (2 Tg, Coynel et al., 2005) this suggests that about a third of the POC delivered by the Congo reaches the lobe area and about a fifth could be preserved by burial (Spencer et al., 2014).

\section{5. OM preservation and fate in lobe sediments}

Our study shows that in the present-day lobe complex, OM is mainly associated with fine silty-clay material, is of continental origin, is relatively homogeneously distributed (Fig. 2) and could be massively accumulating in different areas of this environment (Fig. 5). The 
presence of well-preserved higher plant debris of various sizes in every sample from the recent lobe complex indicates good preservation of the terrestrial OM. The marine, grey colored AOM at site E (Fig. 4a) compared to the aspect of the AOM in sediments of the recent lobe complex (Fig. 4d) probably reflects differences in degradation state. The morphosedimentary features of the northern lobe complex (Babonneau, 2002 and Bonnel, 2005) suggest that the deepest layers of the core COL-E-MTB-14 could date from the Last Glacial Maximum to the early Holocene and thus would give an overview of the OM fate at a millennial time scale for the active area. The preservation state of this OM shows that turbiditic lobe complexes can efficiently preserve OM from remineralization and represents a sink for terrestrial OC in the deep ocean. Considering the studies of Coynel et al. (2005) and Rabouille et al. (2009), a terrestrial OM preservation efficiency of near 20\% was calculated as the ratio of terrestrial OM burial in sediments divided by the rate of its ultimate riverine input. This value agrees with preservation efficiencies obtained for the global seabed (20\% to $44 \%$, Blair and Aller, 2012) and could be refined further for each location on the distal lobe complex with additional sampling. Nonetheless, the potential for OC preservation is important, especially because oxidation of the $\mathrm{OC}$ in this marine environment is limited by the rapid accumulation of sediment (Hedges and Keil, 1995; Spencer et al., 2014).

\section{Conclusion}

This study shows that amounts of terrestrial OM from the Congo River reaching the recent lobe complex of the deep-sea fan are both massive and recent. The terrestrial OM is a mixture of highly degraded soil derived OM, vegetal detritus and other older OC sources, and explains the high sediment OC content (3-5\%).

The initial Congo River load is slightly altered by diagenetic processes and by the addition of heavily degraded marine OM during the turbiditic transfer to the deep-sea demonstrating the potential for OC preservation in this environment. Most of the terrestrial OM is associated 
with silty-clay particles in the lobe complex area, which could explain the homogeneity in OM distribution in the overall region.

Using ${ }^{137} \mathrm{Cs}$ to trace the Congo River terrestrial particle contribution to the lobe complex area, sites $\mathrm{A}$ and $\mathrm{C}$ contain only recent sediments $\left({ }^{137} \mathrm{Cs}\right.$ is present in the entire cores) that have accumulated rapidly, contrary to site B were two distinct deposition periods were characterized. The very low ${ }^{137} \mathrm{Cs}$ signal at site E confirms that it is older and that it is not supplied by turbidites today. At site $\mathrm{C}$, an estimate of the rate of deposition shows that $c a .1$ $\mathrm{kg} . \mathrm{m}^{-2}$ of terrestrial OM could be accumulated each year.

According to seismic data, many old buried lobe complexes exist in the Congo deep-sea fan at the termination point of abandoned channels (Droz et al., 2003 and Marsset et al., 2009). Our results suggest future exploration programmes should include additional coring sites appropriate for generating maps of $\mathrm{OM}$ accumulation and burial in each part of the recent lobe complex and associated with different geological settings. This could then be used to establish a more precise carbon budget for the lobe complex and address the overall OC budget of the Congo deep-sea fan.

\section{References}

Avery, S.V., 1996. Fate of Caesium in the Environment: Distribution Between the Abiotic Components of Aquatic and Terrestrial Ecosystems. Journal of Environmental Radioactivity 30, 139-171.

Babonneau, N., 2002. Mode de fonctionnement d'un chenal turbiditique méandriforme : Cas du système Turbiditique Actuel du Zaïre. Doctoral Thesis Université Bordeaux I, 308 pp.

Babonneau, N., Savoye, B., Cremer, M., Klein, B., 2002. Morphology and architecture of the present canyon and channel system of the Zaire deep-sea fan. Marine and Petroleum Geology $19,445-467$. 
Babonneau, N., Savoye, B., Cremer, M., Bez, M., 2010. Sedimentary Architecture in Meanders of a Submarine Channel: Detailed Study of the Present Congo Turbidite Channel (Zaiango Project). Journal of Sedimentary Research 80, 852-866.

Baudin, F., Disnar, J.-R., Martinez, P., Dennielou, B., 2010. Distribution of the organic matter in the channel-levees systems of the Congo mud-rich deep-sea fan (West Africa). Implication for deep offshore petroleum source rocks and global carbon cycle. Marine and Petroleum Geology 27, 995-1010.

Berger, W.H., 1989. Global maps of ocean productivity, in: Berger, W.H., Smetacek, V.S., Wefer, G. (Eds.), Productivity of the Ocean: Present and Past. Wiley, Dahlem Konferenzen, pp. $429-455$.

Biscara, L., Mulder, T., Martinez, P., Baudin, F., Etcheber, H., Jouanneau, J.M., Garlan, T., 2011. Transport of terrestrial organic matter in the Ogooué deep-sea turbidite system (Gabon). Marine and Petroleum Geology 28, 1061-1072.

Blair, N. E., Aller, R. C., 2012. The fate of terrestrial organic carbon in the marine environment. Annual review of marine science 4, 401-423.

Bonnel, C., 2005. Mise en place des lobes distaux dans les systèmes turbiditiques actuels: Analyse comparée des systèmes du Zaïre,Var et Rhône. Doctoral Thesis Université Bordeaux I, $314 \mathrm{pp}$.

Bouillon, S., Yambélé, A., Spencer, R.G.M., Gillikin, D.P., Hernes, P.J., Six, J., Merckx, R., Borges, A.V., 2012. Organic matter sources, fluxes and greenhouse gas exchange in the Oubangui River (Congo River basin). Biogeosciences 9, 2045-2062. doi:10.5194/bg-9-20452012. 
Burdige, D. J., 2007. Preservation of Organic Matter in Marine Sediments: Controls, Mechanisms, and an Imbalance in Sediment Organic Carbon Budgets? Chemical Reviews 107, 467-485. doi:10.1021/cr050347q

Cai, W.J., 2011. Estuarine and Coastal Ocean Carbon Paradox: $\mathrm{CO}_{2}$ Sinks or Sites of Terrestrial Carbon Incineration? Annual Review of Marine Science 3, 123-145.

Cochran, J.K., 1985. Particle mixing rates in sediments of the eastern equatorial Pacific: Evidence from 210Pb, 239,240Pu and 137Cs distributions at MANOP sites. Geochimica and Cosmochimica Acta 49, 1195-1210.

Coynel, A., Seyler, P., Etcheber, H., Meybeck, M., Orange, D., 2005. Spatial and seasonal dynamics of total suspended sediment and organic carbon species in the Congo River. Global Biogeochemical Cycles 19, GB4019.

De Lange, G.J., 1992. Distribution of exchangeable, fixed, organic and total nitrogen in interbedded turbiditic/pelagic sediment of the Madeira Abyssal Plain, eastern North Atlantic. Marine Geology 109, 95-114.

De Lange, G.J., Van Os, B., Pruysers, P.A., Middelburg, J.J., Castradori, D., Van Santvoort, P., Müller, P.J., Eggenkamp, H., Prahl, F.G., 1994. Possible early diagenetic alteration of palaeo proxies, in: Zahn, R., Pedersen, T.F., Kaminski, M.A., Labeyrie, L. (Eds.), Carbon Cycling in the Glacial Ocean: Constraints on the Ocean's Role in global change. NATO ASI Series I Global Environment Change, 17 pp. 225-251.

Dennielou, B., 2002. Ages et taux d'accumulation du deep-sea fan du Zaïre,. Unpublished report, Rapport Final ZaïAngo: synthèse des éléments de stratigraphie, IFREMER, Brest.

Droz, L., Marsset, T., Ondréas, H., Lopez, M., Savoye, B., Spy-Anderson, F. L., 2003. Architecture of an active mud-rich turbidite system: The Zaire Fan (Congo-Angola margin 
southeast Atlantic): Results from ZaiAngo 1 and 2 cruises. American Association of Petroleum Geologist Bulletin 87, 1145-1168.

Eisma, D., Kalf, J., 1984. Dispersal of Zaire River suspended matter in the estuary and the Angola basin. Netherland Journal of Sea Research 17, 385-411.

Fischer, G., Müller, P.J., Wefer, G., 1998. Latitudinal d13Corg variations in sinking matter and sediments from the South Atlantic: effects of anthropogenic CO2 and implications for paleo-PCO2 reconstructions. Journal of Marine Systems 17, 471-495.

Galy, V., Peucker-Ehrenbrink, B., Eglinton, T., 2015. Global carbon export from the terrestrial biosphere controlled by erosion. Nature 521(7551), 204-207.

Goñi, M. A., 1997. Record of terrestrial organic matter composition in amazon fan sediments. Proceeding of the Ocean Drilling Program, Scientific Results, 155, 519-530.

Hale, R. P., Nittrouer, C. A., Liu, J. T., Keil, R. G., Ogston, A. S., 2012. Effects of a major typhoon on sediment accumulation in Fangliao Submarine Canyon, SW Taiwan. Marine Geology 326-328, 116-130.

Hamilton, E.L., 1976. Variations of density and porosity with depth in deep-sea sediments. Journal of Sedimentary Petrology 46, 280-300.

Hancock, G.R., Murphy, D.V., Li, Y., 2013. Soil properties and environmental tracers: A (DEM) based assessment in an Australian Mediterranean environment. Geomorphology 183, $45-57$.

Hedges, J.I., Keil, R.G., 1995. Sedimentary organic matter preservation: an assessment and speculative synthesis. Marine Chemistry 49, 81-115.

Hedges, J.I., Oades, J.M., 1997. Comparative organic geochemistries of soils and marine sediments. Organic Geochemistry 27, 319- 361. 
Hedges, J. I., Keil, R. G., Benner, R., 1997. What happens to terrestrial organic matter in the ocean? Organic Geochemistry 27, 195-212.

Heezen, B.C., Menzies, R. J., Schneider, E.D., Ewing,W. M., Granelli, N. C. L., 1964. Congo submarine canyon. Bulletin of the American Association Petroleum Geologists 48, 11261149.

Holmes, M. E., Müller, P. J., Schneider, R. R., Segl, M., Pätzold, J., Wefer, G., 1996. Stable nitrogen isotopes in Angola Basin surface sediments. Marine Geology 134, 1-12.

Holtvoeth, J., Wagner, T., Schubert, C.J., 2003. Organic matter in river-influenced continental margin sediments: The land-ocean and climate linkage at the Late Quaternary Congo fan (ODP Site 1075). Geochemistry Geophysics Geosystems 4 (12).

Jansen, J. H. F., Van Weering, T. C. E., Gieles, R., Van Iperen, J., 1984. Middle and late Quaternary oceanography and climatology of the Zaire-Congo fan and the adjacent eastern Angola Basin. Netherlands Journal of Sea Research 17, 201-249.

Keil, R. G., Tsamakis, E., Wolf, N., Hedges, J.I., Goñi, M.A., 1997. Proceeding of the Ocean Drilling Program, Scientific Results, 155, 531-538.

Khripounoff, A., Vangriesheim, A., Babonneau, N., Crassous, P., Dennielou, B., Savoye, B., 2003. Direct observation of intense turbidity current activity in the Zaire submarine valley at 4000 m water depth. Marine Geology 194, 151-158.

Kim, Y., Cho, S., Kang, H. D., Kim, W., Lee, H. R., Doh, S. H., Kim, K., Yun, S. G., Kim, D. S., Jeong, G.Y., 2006. Radiocesium reaction with illite and organic matter in marine sediment. Marine Pollution Bulletin 52, 659-665. 
Laraque, A., Olivry, B., 1996. Evolution de l'hydrologie du Congo-Zaïre et de ses affluents rive droite et dynamique des transports solides et dissous, in: Chevalier, P., Pouyaud, B. (Eds.), Tropical Hydrology: A Geoscience and a Tool for Sustainnability. AISH., pp. 435.

Laraque, A., Castellanos, B., Steiger, J., Lòpez, J. L., Pandi, A., Rodriguez, M., Rosales, J., Adèle, G., Perez, J., Lagane, C., 2013. A comparison of the suspended and dissolved matter dynamics of two large inter-tropical rivers draining into the Atlantic Ocean: the Congo and the Orinoco. Hydrological Processes 27, 2153-2170.

Laraque A, Mahe G, Orange D, Marieu B., 2001. Spatiotemporal variations in hydrological regimes within Central Africa during the XXth century. Journal of Hydrology 245, 104-117.

Legeleux, F., Reyss, J. L., Schmidt, S., 1994. Particle mixing rates in sediments of the northeast tropical Atlantic: Evidence from PbXS-210, Cs-137, ThXS-228 and ThXS-234 downcore distributions. Earth and Planetary Science Letters 128, 545-562.

Mariotti, A., Gadel, F., Giresse, P., Mouzéo, K., 1991. Carbon isotope composition and geochemistry of particulate organic matter in the Congo River (Central Africa): application to the study of Quaternary sediments off the mouth of the river. Chemical Geology (Isotope Geoscience Section) 86, 345-357.

Marsset, T., Droz, L., Dennielou, B., Pichon, E., 2009. Cycles in the architecture of the quaternary Zaire turbidite system: a possible link with climate. External Controls on DeepWater Depositional Systems 92, 89-106.

Mc Kee, B.A., Aller, R.C., Allison, M.A., Bianchi, T.S., Kineke, G.C., 2004. Transport and transformation of dissolved and particulate materials on continental margins influenced by major rivers: benthic boundary layer and seabed processes. Continental Shelf Research 24, 899-926. 
Meybeck, M., 1993. Riverine transport of atmospheric carbon: sources, global typology and budget. Water, Air and Soil Pollution 70, 443-463.

Meyers, P. A., 1994. Preservation of elemental and isotopic source identification of sedimentary organic matter. Chemical Geology 114, 289-302.

Meyers, P. A., 1997. Organic geochemical proxies of paleoceanographic, paleolimnologic, and paleoclimatic processes. Organic Geochemistry 27, 213-250.

Mollenhauer, G., Schneider, R.R., Jennerjahn, T., Müller, P.J., Wefer, G., 2004. Organic carbon accumulation in the South Atlantic Ocean: its modern, mid-Holocene and last glacial distribution. Global and Planetary Change 40, 249-266.

Müller, G., Gastner, M., 1971. The 'Karbonat-Bombe', a simple device for the determination of carbonate content in sediment, soils, and other materials. Neues Jahrbuch für MineralogieMonatshefte 10, 466-469.

Müller, P. J., Suess, E., 1979. Productivity, sedimentation rate, and sedimentary organic matter in the oceans-I. Organic carbon preservation. Deep-sea Research Part A. Oceanographic Research Papers 26, 1347-1362.

Müller, P. J., Schneider, R., Ruhland, G., 1994. Late Quaternary pCO2 variations in the Angola current: evidence from organic carbon $\delta 13 \mathrm{C}$ and alkenone temperatures, in: Zahn, R., Pedersen, T.F., Kaminski, M.A., Labeyrie, L. (Eds.), Carbon Cycling in the Glacial Ocean: Constraints on the Ocean's Role in global change. NATO ASI Series I Global Environment Change, 17 pp. 343-361.

Rabouille, C., Caprais, J. C., Lansard, B., Crassous, P., Dedieu, K., Reyss, J. L., Khripounoff, A., 2009. Organic matter budget in the Southeast Atlantic continental margin close to the 
Congo Canyon: In situ measurements of sediment oxygen consumption. Deep-sea Research II $56,2223-2238$.

Reyss, J.L., Schmidt, S., Legeuleux, F., Bonte, P., 1995. Large low background well-type detectors for measurements of environmental radioactivity. Nuclear Instruments and Methods in Physics Research 357, 391-397.

Richey, J. E., Brook, J.T., Naiman, R. J., Wissmar, R. C., Stallard, R. F., 1980. Organic carbon: oxidation and transport in the Amazon River. Science 207, 1348-1351.

Ritchie, J. C., Mc Henry, J. R., 1990. Application of Radioactive Fallout Cesium-137 for Measuring Soil Erosion and Sediment Accumulation Rates and Patterns: A Review. Journal of Environment al Quality 19, 215-233.

Savoye, B., Babonneau, N., Dennielou, B., Bez, M., 2009. Geological overview of the Angola-Congo margin, the Congo deep-sea fan and its submarine valleys. Deep-sea Research II 56, 2169-2182.

Savoye, B., Cochonat, P., Apprioual, R., Bain, O., Baltzer, A., Bellec, V., Beuzart, P., Bourillet, J. F., Cagna, R., Cremer, M., others., 2000. Structure et évolution récente de l'éventail turbiditique du Zaïre: premiers résultats scientifiques des missions d'exploration Zaïango1 \& 2 (marge Congo-Angola). Comptes Rendus de l'Académie des Sciences-Series IIA-Earth and Planetary Science 331, 211-220.

Schefuss, E., Versteegh, G.J., Jansen, J.H., Sinninghe Damsté, J., 2004. Lipid biomarkers as major source and preservation indicators in SE Atlantic surface sediments. Deep-sea Research I 51, 1199-1228. 
Schlünz, B., Schneider, R. R., 2000. Transport of terrestrial organic carbon to the oceans by rivers: re-estimating flux-and burial rates. International Journal of Earth Sciences 88, 599606.

Schlünz, B., Schneider, R. R., Müller, P., Showers, W., Wefer, G., 1999. Terrestrial organic carbon accumulation on the Amazon deep-sea fan during the last glacial sea level low stand. Chemical Geology 159, 263-281.

Selvaraj, K., Lee, T. Y., Yang, J. Y. T., Canuel, E. A., Huang, J. C., Dai, M., Liu, J. T., Kao, S. J., 2015. Stable isotopic and biomarker evidence of terrigenous organic matter export to the deep-sea during tropical storms. Marine Geology 364, 32-42.

Seyler, P., Coynel, A., Moreira Turcq, P., Etcheber, H., Colas, C., Orange, D., Bricquet, J. P., Laraque, A., Guyot, J. L., Olivry, J. C., Meybeck, M., 2004. Organic carbon transported by the Equatorial rivers : example of Congo-Zaire and Amazon basins, in: Roose, E., Lal, R., Feller, C., Barthès, B., Stewart, B.A. (Eds.), Land Uses, Erosion and Carbon Sequestration : International Colloquium, Montpellier (FRA). Soil Erosion and Carbon Dynamics, Advances in Soil Science, pp. 255-274.

Sibuet, M., Vangriesheim, A., 2009. Deep-sea environment and biodiversity of the West African Equatorial margin. Deep-sea Research Part II Topical Study in Oceanography 56, 2156-2168.

Spencer, R. G. M., Hernes, P. J., Aufdenkampe, A. K., Baker, A., Gulliver, P., Stubbins, A., Aiken, G. R., Dyda, R.Y., Butler, K.D., Mwamba, V. L., Mangangu, A. M., Wabakanghanzi, J. N., Six, J., 2012. An initial investigation into the organic matter biogeochemistry of the Congo River. Geochimica and Cosmochimica Acta 84, 614-627.

Spencer, R. G. M., Stubbins, A., Gaillardet, J., 2014. Geochemistry of the Congo River, estuary and plume, in : Bianchi, T. S., Allison, M. A., Cai, W. J. (Eds.), Biogeochemical 
dynamics at Major River-Coastal Interfaces Linkages with Global Change. Cambridge University press, pp. 3-18.

Sperazza, M., Moore, J. N., Hendrix, M. S., 2004. High-resolution particle size analysis of naturally occurring very fine-grained sediment through laser diffractometry. Journal of Sedimentary Research 74, 736-743.

Talbot, H. M., Handley, L., Spencer-Jones, C. L., Bienvenu, D. J., Schefuss, E., Mann, P. J., Poulsen, J. R., Spencer, R. G. M., Wabakanghanzi, J. N., Wagner, T. 2014. Variability in aerobic methane oxidation over the past 1.2 Myrs recorded in microbial biomarker signatures from Congo fan sediments. Geochimica et Cosmochimica Acta 133, 387-401.

Treignier, C., 2005. Apports en matière organique marine et terrigène sur la marge équatoriale ouest africaine : rôle joué par le canyon sous-marin du Zaïre. Approche par les biomarqueurs lipidiques. Doctoral Thesis Université Pierre et Marie Curie, 129 pp.

Twichell, S. C., Meyers, P. A., Diester-Haass, L., 2002. Significance of high C/N ratios in organic-carbon-rich Neogen sediments under the Benguela Current upwelling system. Organic Geochemistry 33, 715-722.

Tyson, R. V., 1995. Sedimentary Organic Matter: Organic Facies and Palynofacies. Chapman \& Hall, London, 615 pp.

Van Bennekom, A. J., Berger, G. W., 1984. Hydrography and silica budget of the Angola Basin. Netherlands Journal of Sea Research 17, 149-200.

Vangriesheim, A., Pierre, C., Aminot, A., Metzl, N., Baurand, F., Caprais, J. C., 2009. The influence of Congo River discharges in the surface and deep layers of the Gulf of Guinea. Deep-sea Research II 56, 2183-2196. 
Van Weering, T. C. E., De Stigter, H. C., Boer, W., De Haas, H., 2002. Recent sediment transport and accumulation on the NW Iberian margin. Progress in Oceanography 52, 349371.

Walsh, J. P., Nittrouer, C. A., 2003. Contrasting styles of off-shelf sediment accumulation in New Guinea. Marine Geology 196, 105- 125.

Walsh, J. P., Nittrouer, C. A., 2009. Understanding fine-grained river-sediment dispersal on continental margins. Marine Geology 263, 34-45.

Weijers, J. W. H., Schouten, S., Schefuss, E., Schneider, R. R., Sinninghe Damsté, J. S., 2009. Disentangling marine, soil and plant organic carbon contributions to continental margin sediments: A multi-proxy approach in a 20,000 year sediment record from the Congo deepsea fan. Geochimica and Cosmochimica Acta 73, 119-132.

Wenzhöfer, F., Glud, R. N., 2002. Benthic carbon mineralization in the Atlantic: a synthesis based on in situ data from the last decade. Deep-sea Research I 49, 1255-1279.

Wetzel, A., 1993. The transfer of river load to deep-sea fans: a quantitative approach. american association of petroleum geologists bulletin 77, 1679-1692.

Worldwide marine radioactivity studies (WOMARS) Radionuclide levels in oceans and seas Final report of a coordinated research project., 2005. International Atomic Energy Agency, pp 187.

Zalasiewicz, J., Waters, C. N., Williams, M., Barnosky, A. D., Cearreta, A., Crutzen, P., Ellis, E., Ellis, M. A., Fairchild, I. J., Grinevald, J., Haff, P. K., Hajdas, I., Leinfelder, R., McNeill, J., Odada, E. O., Poirier, C., Richter, D., Steffen, W., Summerhayes, C., Syvitski, J. P. M., Vidas, D., Wagreich, M., Wing, S. L., Wolfe, A. P., An, Z., Oreskes, N., 2015. When did the 
Anthropocene begin? A mid-twentieth century boundary level is stratigraphically optimal.

Quaternary International in press.

Figure and Table captions

Graphical abstract

Relationship between stable isotopes of nitrogen and carbon measured on OM in all the cores analyzed ( $\mathrm{n}=94)$ in the overall recent and abandoned lobe complexes. The majority of points are tightly clustered and associated with the deep sea fan environment; these have isotopic signatures typical of C3 plants. Each box is constructed with data from different sources. Congo River data are from Mariotti et al. (1991) and Spencer et al. (2012). "Active zone" illustrates the recent lobe complex where turbiditic inputs dominate (data from this study and Baudin et al. (2010)). "Abandoned zone" illustrates the northern lobe complex and other parts of the Congo deep sea fan where pelagic inputs dominate (data from this study, Holmes et al. (1996), Müller et al. (1994) and Schefuss et al. (2004)). Marine POM data are from Tyson (1995), Meyers (1997), Fischer et al. (1998) and Schefuss et al. (2004).

Figure 1. The study area is located on the Congo deep-sea fan, about $760 \mathrm{~km}$ offshore from the mouth of the Congo River, in the abyssal southeastern Atlantic Ocean. (a) Lobe area is at the distal end of the active channel (red), KZAI cores data are from Baudin et al. (2010). (b) Enlargement of the area where the five sites analyzed in this study are mapped on a high resolution view of the lobe area (modified from EM12 sonar imagery; Savoye et al., 2000 and Babonneau, 2002). The recent lobe complex covers $3000 \mathrm{~km}^{2}$ and represents ca. $1 \%$ of the total Congo deep-sea fan area (Savoye et al., 2000). The northern lobe complex is older (Babonneau, 2002). Similar, older buried lobe complexes have been mapped all over the Congo deep-sea fan at the termination of abandoned channels (Droz et al., 2003 and Marsset et al., 2009). (c) Locations for POC biogeochemistry samples and data for terrestrial end 
member materials collected at the entrance to the Malebo Pool (Mariotti et al., 1991) and Kinshasa-Brazzaville station downstream (Spencer et al., 2012).

Figure 2. Geochemical and grain size data for all cores from each site presented in Tables 1 and 3.

Figure $3 .{ }^{137} \mathrm{Cs}$ profiles measured on cores from sites A, C, B and E.

Figure 4. Microscope imagery of palynofacies slides from materials collected at site E (abandoned zone) and at site A-levee (recent or active zone). a) illustrates the horizon 1-2 cm in which amorphous $\mathrm{OM}$ of grey color dominates, indicating that amorphous OM is not well preserved. There are also residual phytoclasts that are not well-preserved suggesting a minor terrestrial contribution. b) illustrates horizon $16-19 \mathrm{~cm}$ where dominant particles are higher plant debris of various sizes, the ligno-cellulosic debris presents discernible vegetal fiber. Marine palynomorphs also occur. c) illustrates the last horizon where terrestrial contribution is clearly high with well-preserved higher plant debris. d) illustrates the presence of AOM observed for the site $\mathrm{A}$ on the levee for the horizon $0.5-1 \mathrm{~cm}$. AOM has a more orange color when compared to the surface sediment AOM observed at the site E. Images e) and f) show the enrichment in well-preserved terrestrial $\mathrm{OM}$ at site A for the horizon $16-19 \mathrm{~cm}$ (cell wall structures are obvious features in continental-derived material), as observed in horizon 19-22 $\mathrm{cm}$ at site $\mathrm{E}$ (illustrated in image c).

Figure 5. Evolution of the turbiditic deposits, porosity, $\%$ OC, $\mathrm{C}: \mathrm{N}, \delta^{13} \mathrm{C}_{\mathrm{org}}$, and ${ }^{137} \mathrm{Cs}$ in the long core from site $\mathrm{C}$ indicating the high homogeneity in distribution of $\mathrm{OC}$ along the sediment column and the high, short time scale of deposits. Between 0 and $170 \mathrm{~cm}$, there are 12 turbidites when taking into account the silty-clay intervals (the " $\mathrm{T}$ " indicates a single turbiditic deposit). Between 170 and $408 \mathrm{~cm}$, there are silty-clay intervals, one fine sand interval and slump deformation structures which are not visible at the scale of the figure. 
Between 408 and $611 \mathrm{~cm}$, silty-clay intervals are always present with clay clasts and numerous plant debris. Between 611 and $698 \mathrm{~cm}$ we identified a block of compacted clay, inclined layers at $30^{\circ}$ (interpreted as a transported block). Between $698 \mathrm{~cm}$ to the base of the core, silts to very fine sands dominate and are rich in plant debris. Plant debris were observed throughout the entire core.

Figure 6. Relation between the $\mathrm{OC}$ content in the cores from all five sites and the $\delta^{13} \mathrm{C}$ results. Filled symbols are for material from the sites in or near the active channel, the crosses are from the OM collected in an area not currently undergoing active deposition (site E). The values from the distal area (site C) are enclosed by the oval shape and lie at the upper end of the range. The terrestrial end member for coarse POM (CPOM) and fine POM (FPOM) are reported (star symbols, Spencer et al., 2012). The marine limit for $\delta^{13} \mathrm{C}$ is also shown (grey bar on right). The marine $\mathrm{OM} \delta{ }^{13} \mathrm{C}_{\mathrm{org}}$ end-member was selected based on the range of data reported from the Gulf of Guinea (Fischer et al., 1998, Baudin et al., 2010 and Biscara et al., 2011).

Figure 7. Relationship between stable isotopes of nitrogen and carbon measured on OM in all the cores analyzed $(n=94)$. The majority of points are tightly clustered and associated with the deep-sea fan environment; these have isotopic signatures typical of $\mathrm{C} 3$ plants. Each box is constructed with data from different sources. Congo River data are from Mariotti et al. (1991) and Spencer et al. (2012). "Active zone" illustrates the recent lobe complex where turbiditic inputs dominate (data from this study and Baudin et al. (2010)). "Abandoned zone" illustrates the northern lobe complex and other parts of the Congo deep-sea fan where pelagic inputs dominate (data from this study, Holmes et al. (1996), Müller et al. (1994) and Schefuss et al. (2004)). The northern lobe complex straddles the two boxes. The $(0-7 \mathrm{~cm})$ horizons from site $\mathrm{E}$ are in the abandoned zone box (these horizons are in red), the horizons $(7-10 \mathrm{~cm})$ and $(10-$ $13 \mathrm{~cm})$ are located at the transition between the two boxes. The deeper horizons $(13-22 \mathrm{~cm})$ 
are present in the recent lobe complex box. Marine POM data are from Tyson (1995), Meyers (1997), Fischer et al. (1998) and Schefuss et al. (2004). The arrow at the top indicates the direction of expected decreasing contribution by terrestrial OM.

Table 1. Locations, depths and geological context of the cores analyzed in this study. One to five separate cores were analyzed from each of five different depositional settings on the lobe sediments (Fig.1b). Cores from the WACS cruise were collected in 2011-2012 and those from Congolobe (COL prefix) were collected in 2012-2013 (Results from campaign report WACS and CONGOLOBE:

http://www.ifremer.fr/biocean/acces_fr/rapports/Appel_1cruiselistfr.htql). *COL-C-MTB-10 has been used for granulometry analysis and COL-C-MTB-11 for geochemical analysis. It is considering that the two cores are very close in terms of sediment properties.

Table 2. Categories of palynofacies identified in this study.

Table 3. Weighted mean, maximum and minimum values for OC $(\%), \delta{ }^{15} \mathrm{~N}(\%), \delta{ }^{13} \mathrm{C}_{\mathrm{org}}(\%)$ and $\mathrm{C}: \mathrm{N}$ (molar ratio) from the short $(22 \mathrm{~cm}$ ) cores at all five sites. The nature of the organic materials at Site E is significantly different from all other sites. Details of down core trends from sites A and E are shown in Figure 2. *COL-C-MTB-10 has been used for granulometry analysis and COL-C-MTB-11 for geochemical analysis, considering that the two cores are very close in terms of sediment properties. 


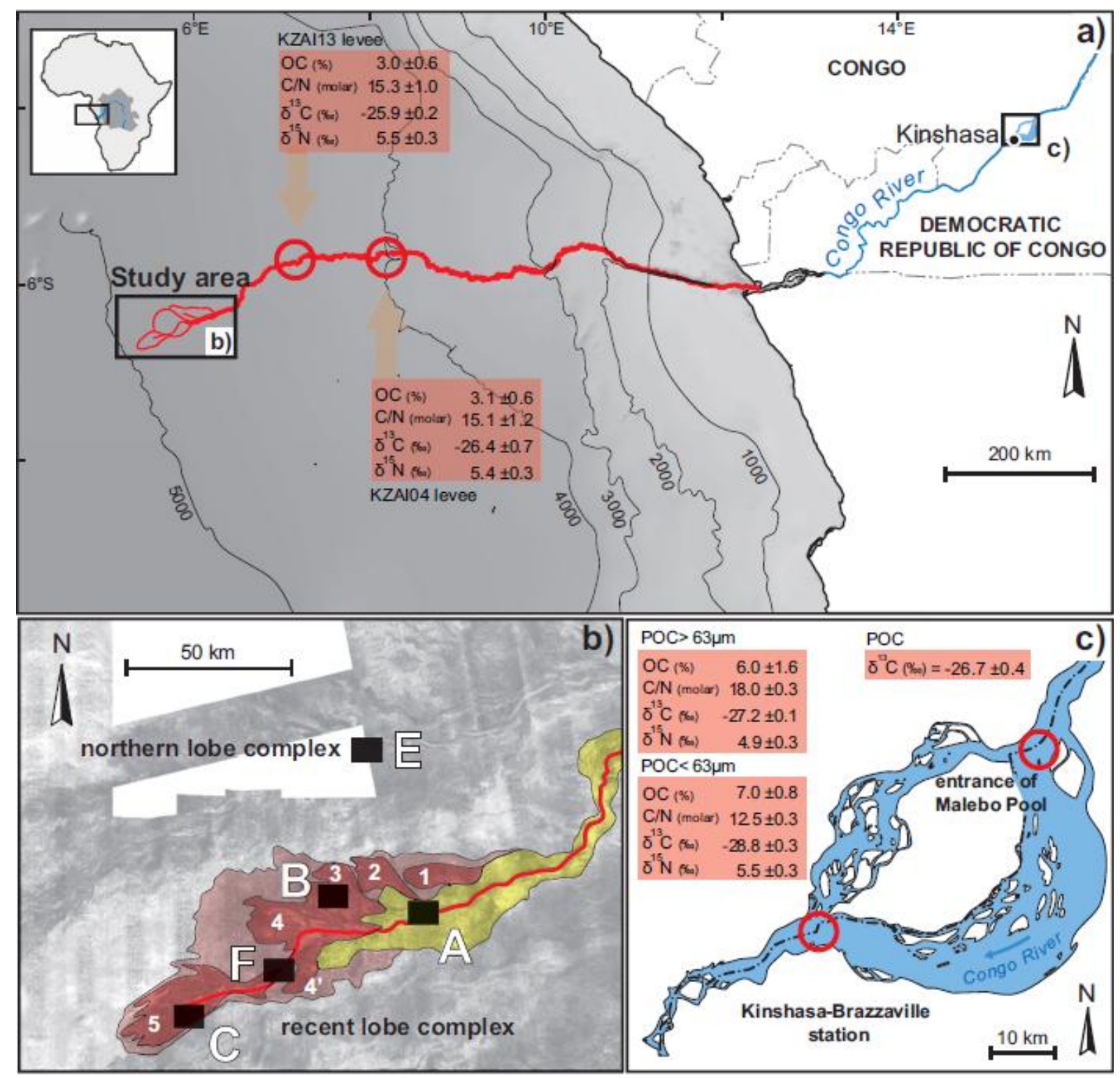

Figure 1 


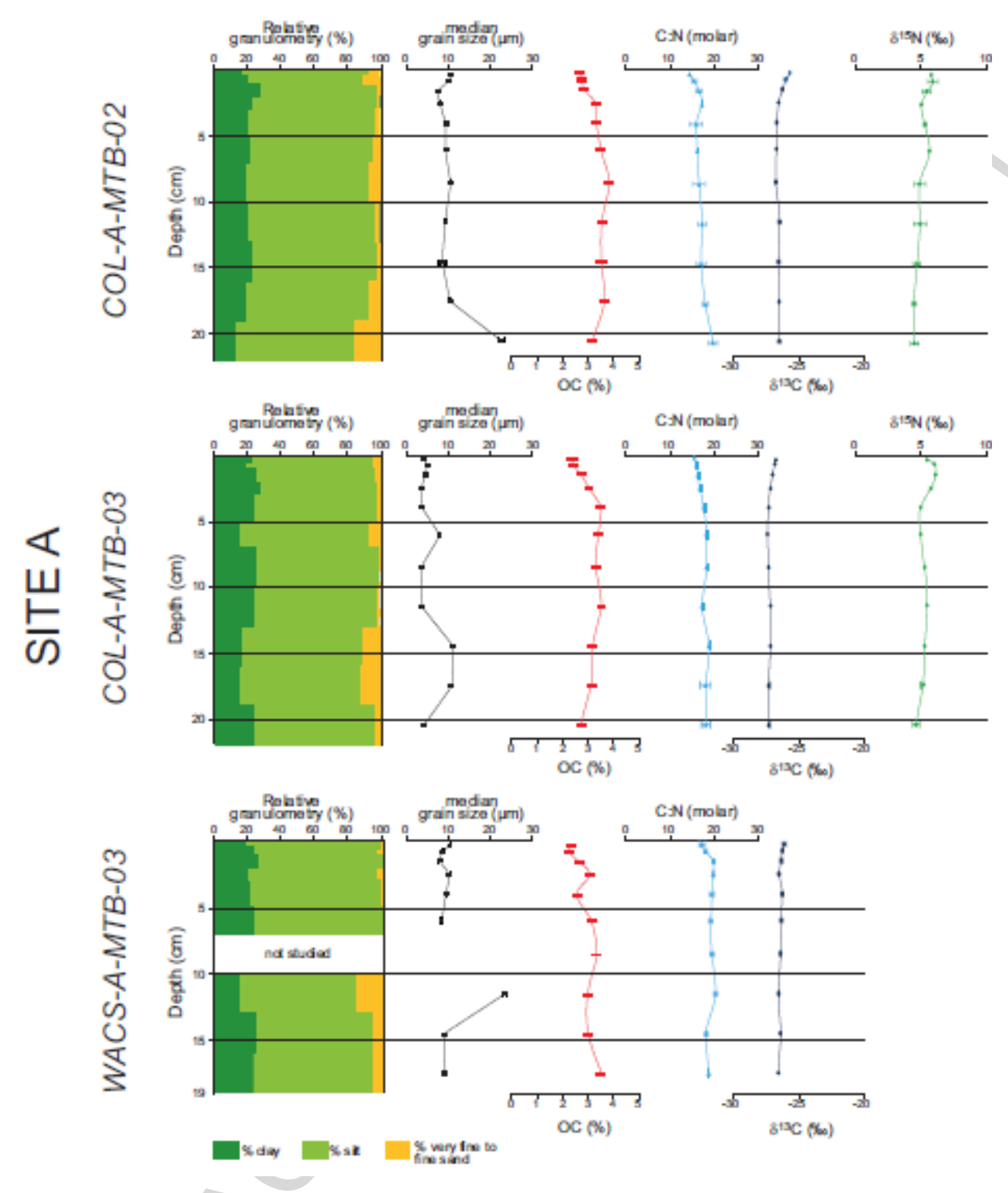

Figure 2A 


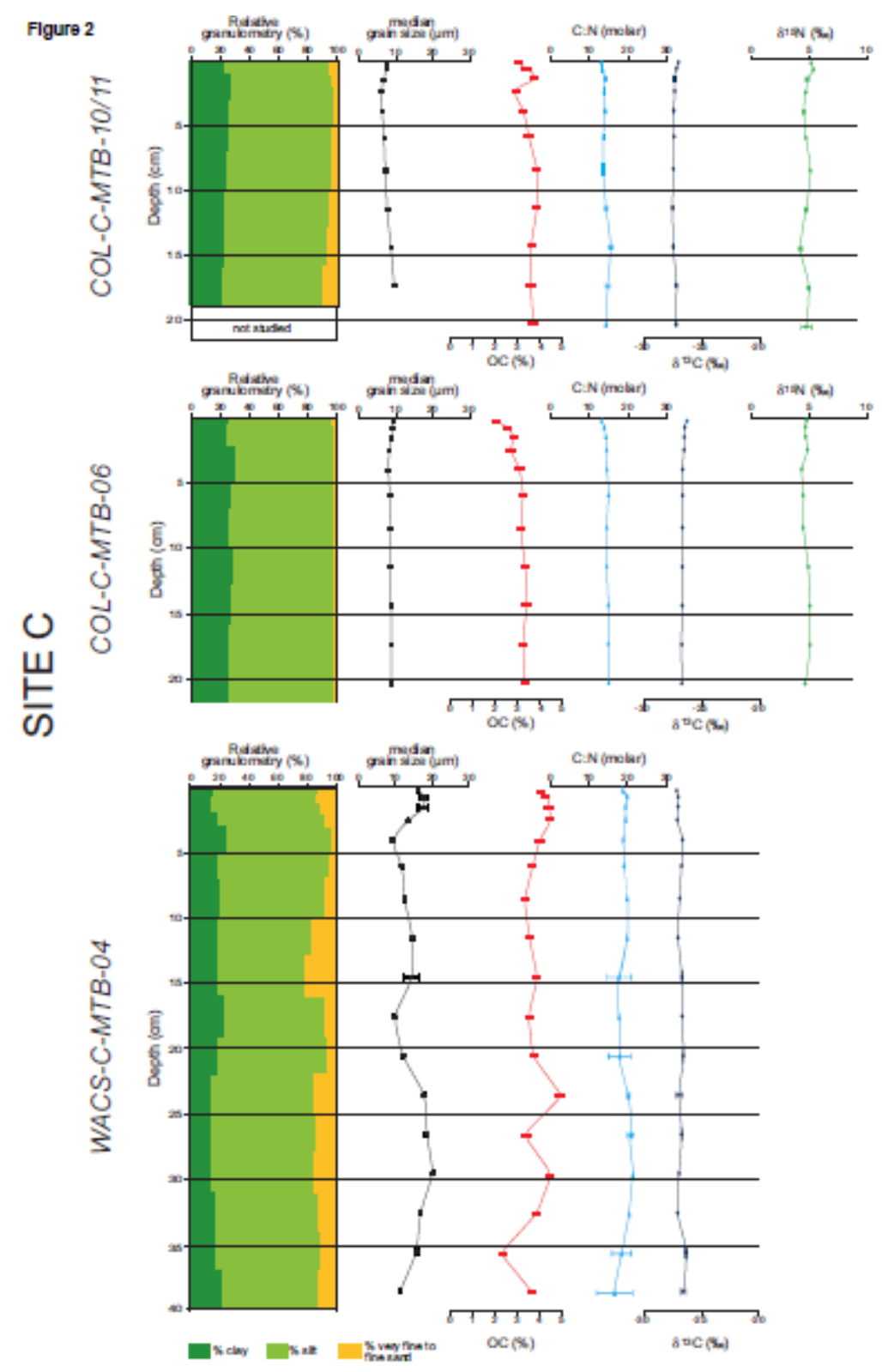

Figure 2B 
Figure 2
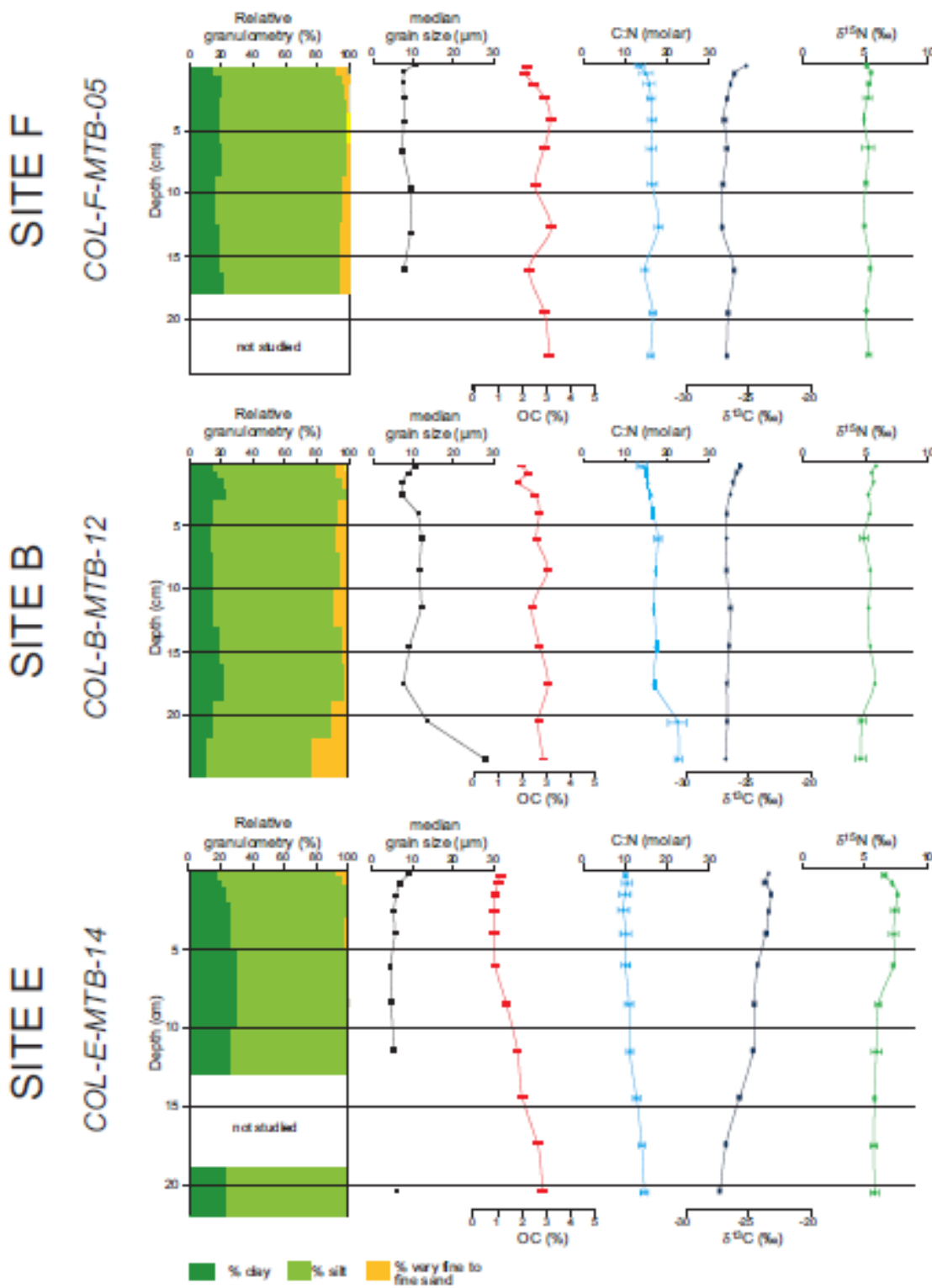

Figure 2C 


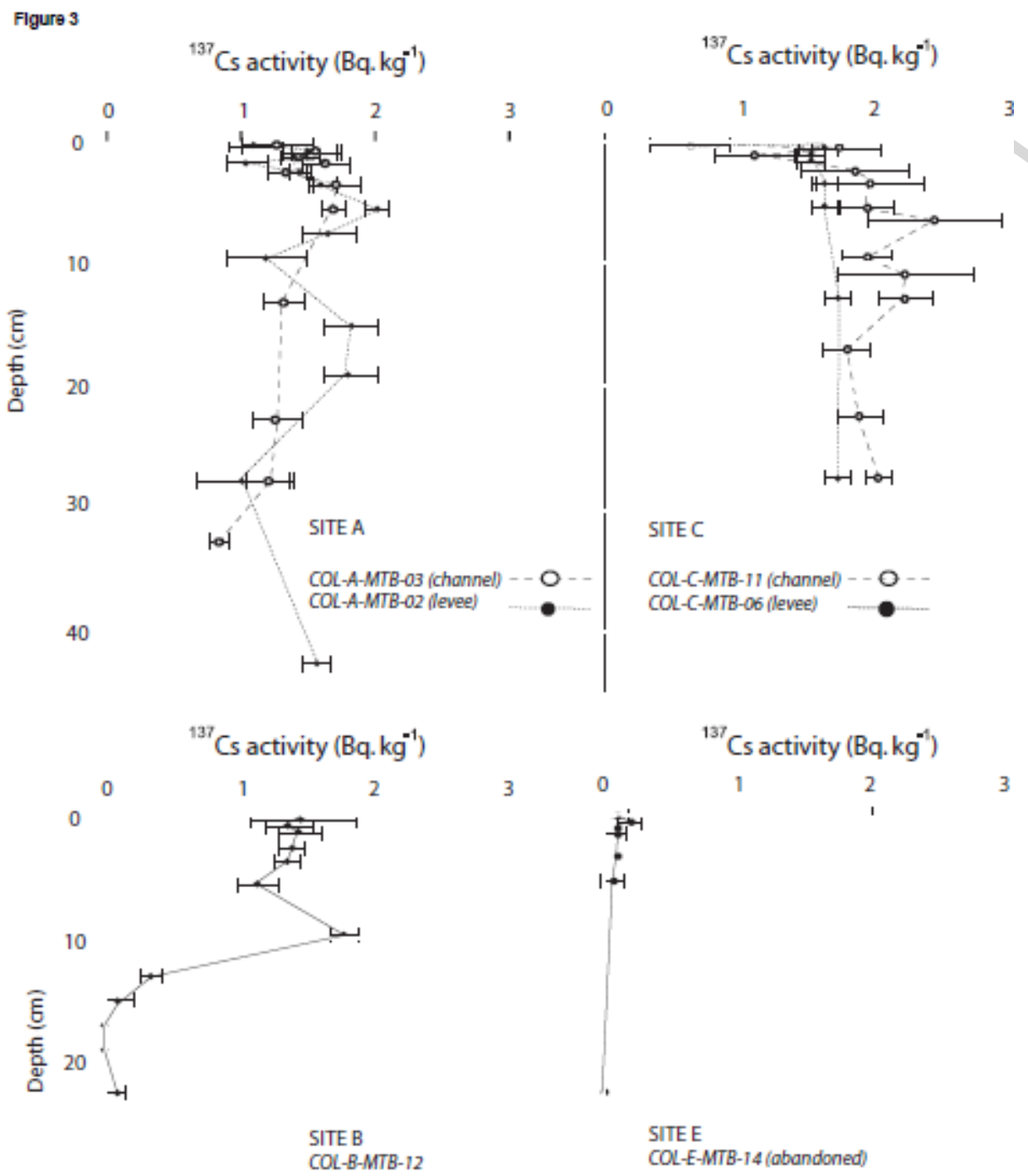

Figure 3 


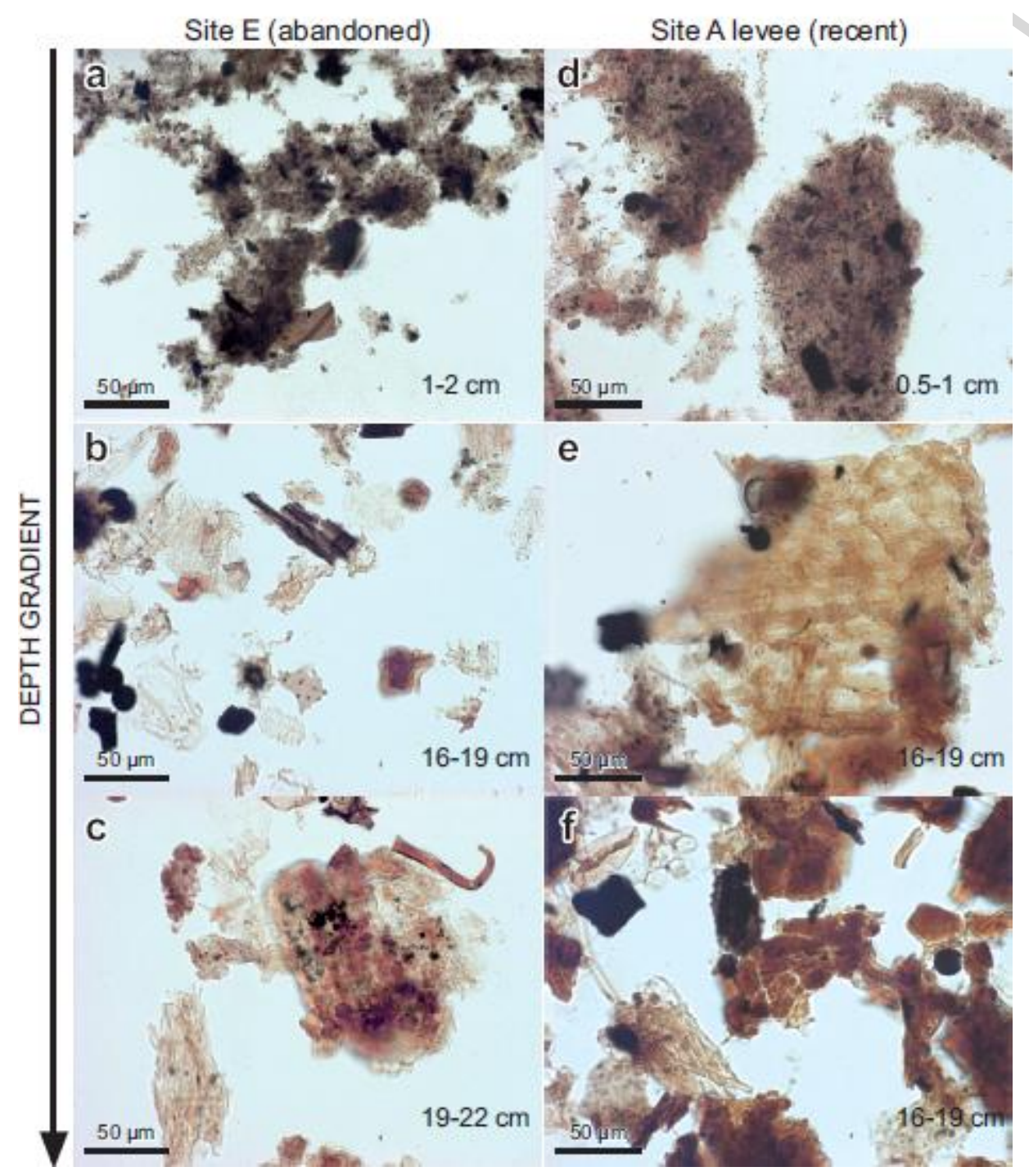

Figure 4 
Figure 5

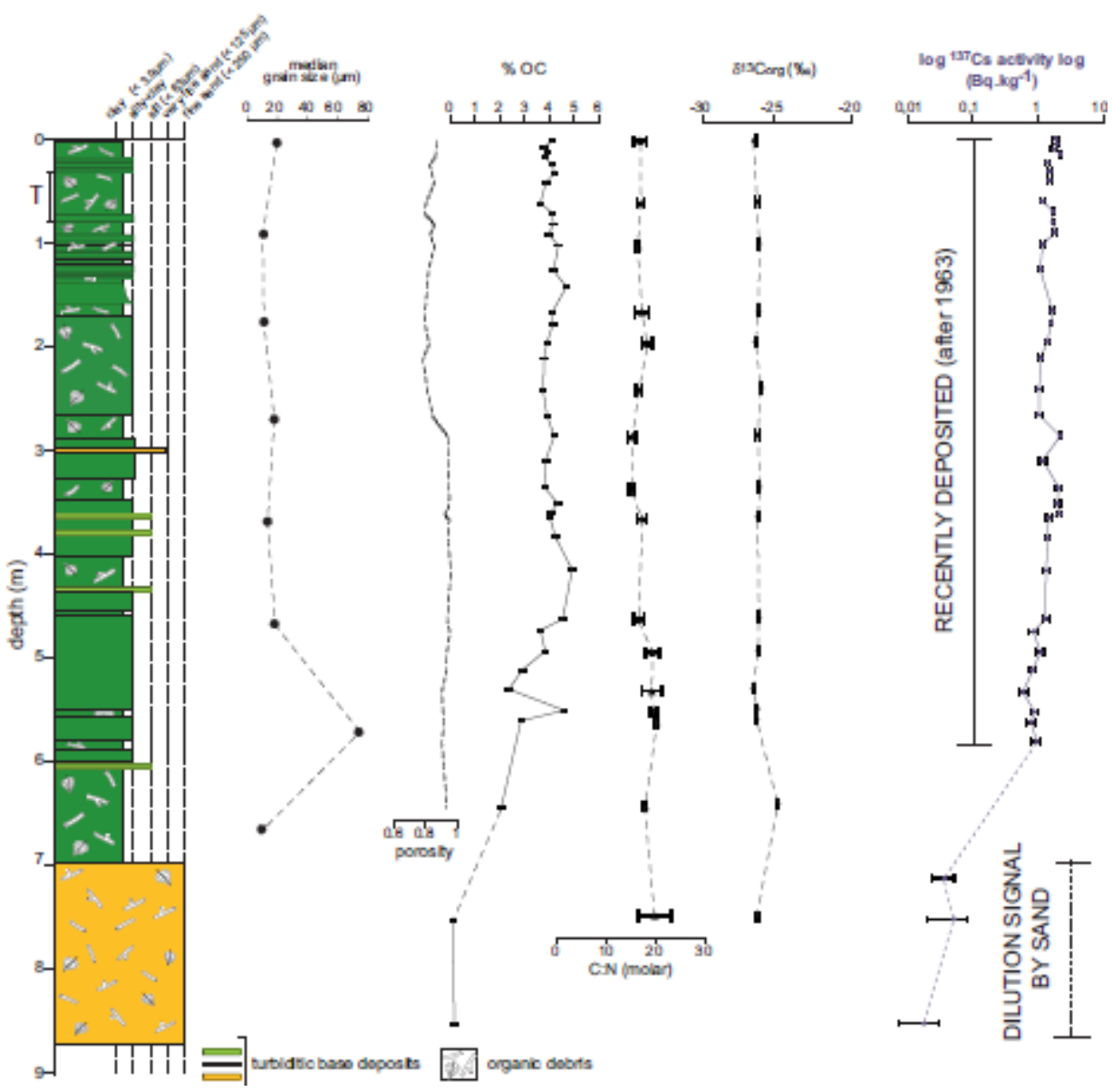

Figure 5 
Figure 6

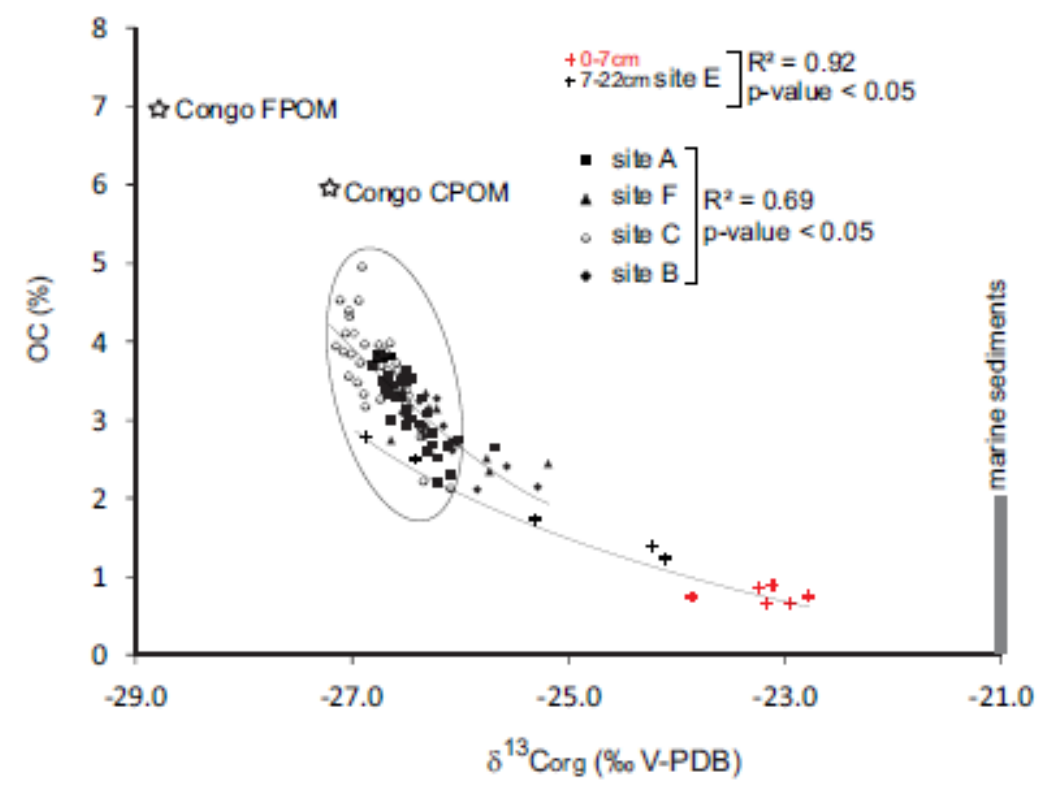

Figure 6 
Figure 7

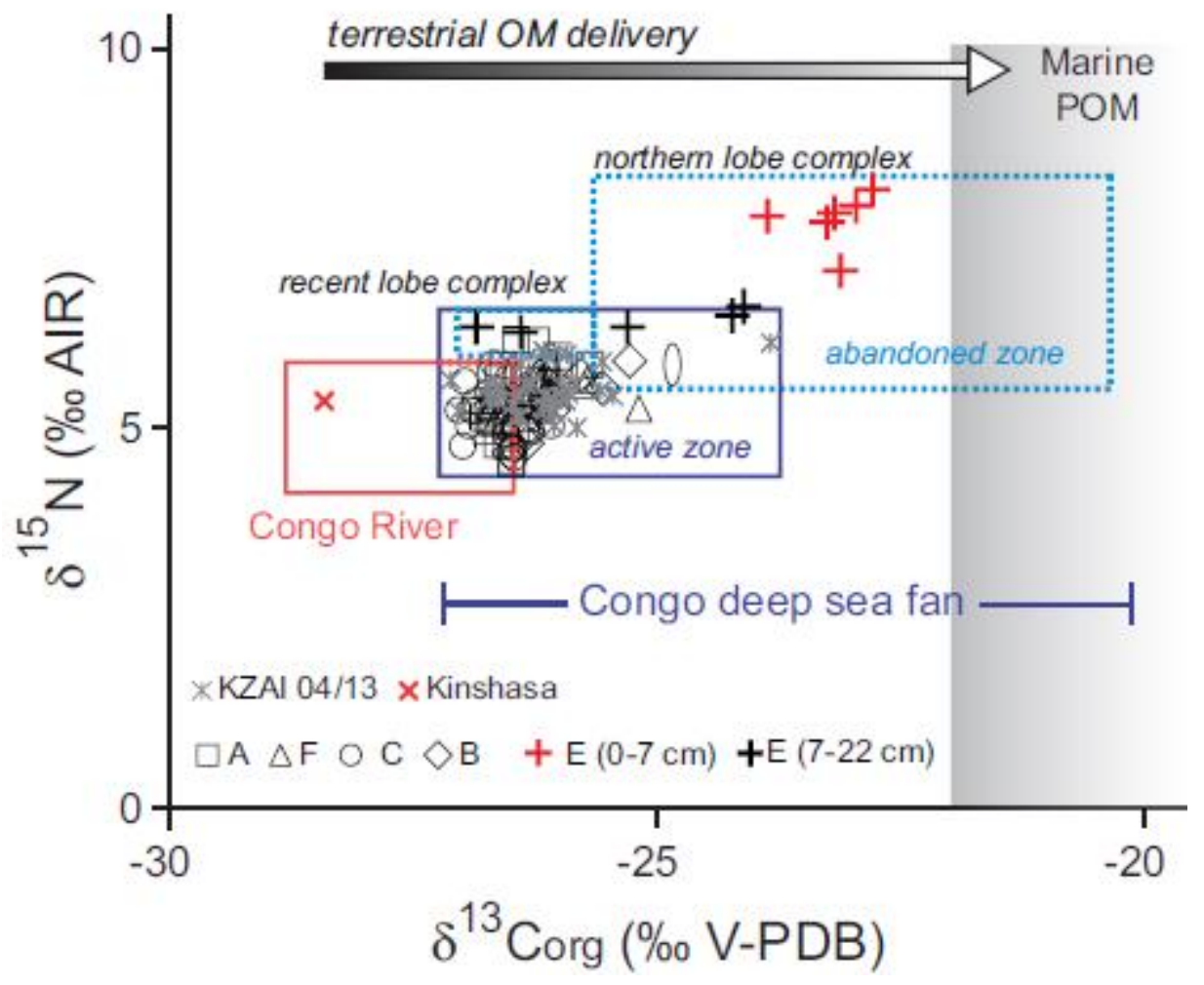

Figure 7 


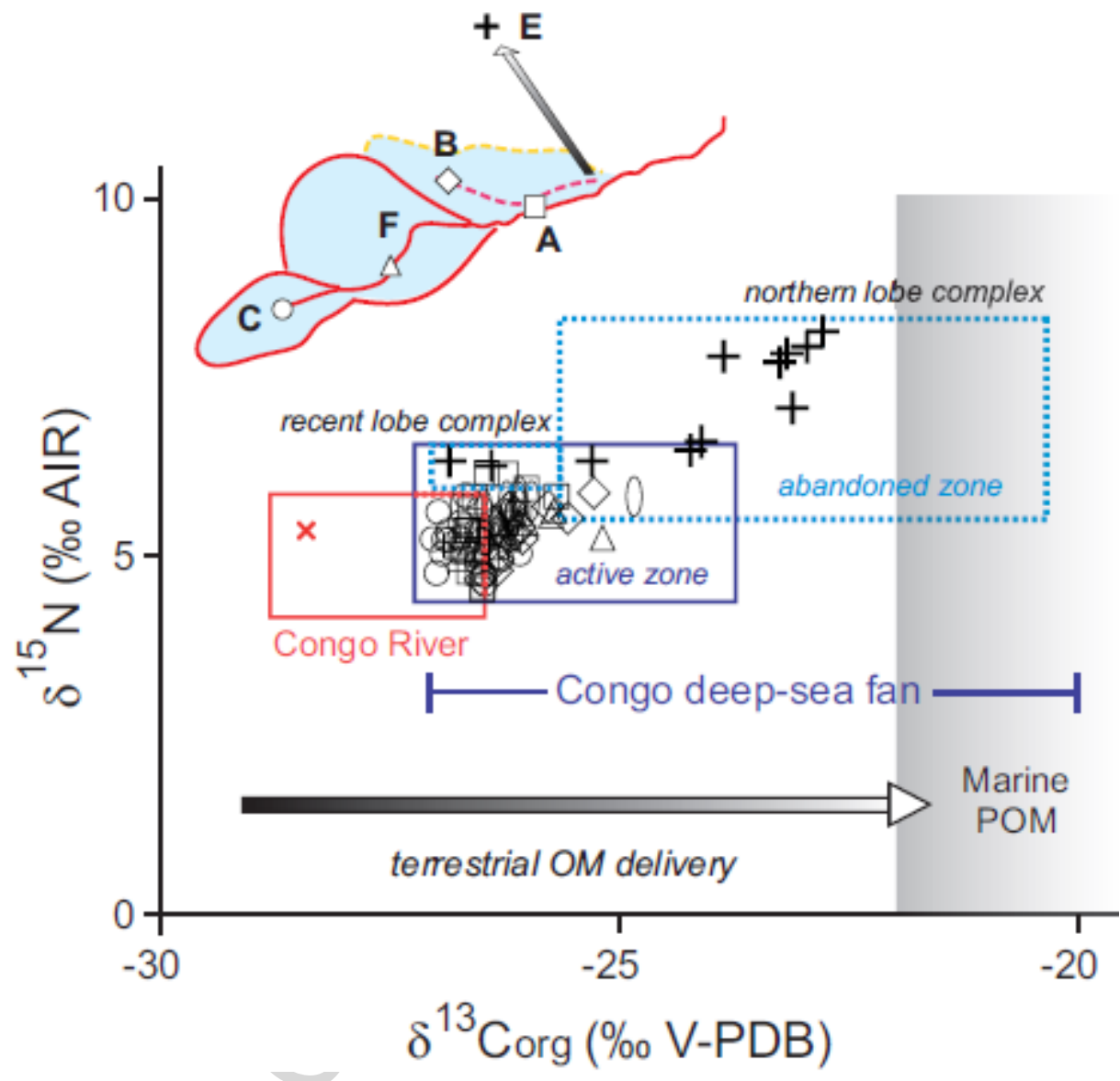

Graphical abstract 
Table 1

\begin{tabular}{|c|c|c|c|c|c|c|c|}
\hline Site & $\begin{array}{l}\text { Leg and } \\
\text { core name }\end{array}$ & $\begin{array}{l}\text { Core } \\
\text { length } \\
(\mathrm{cm})\end{array}$ & $\begin{array}{l}\text { Lat } \\
\left({ }^{\circ} \mathbf{S}\right)\end{array}$ & $\begin{array}{l}\text { Lon } \\
\left({ }^{\circ} \mathbf{E}\right)\end{array}$ & $\begin{array}{c}\text { Water- } \\
\text { depth } \\
\text { (m) }\end{array}$ & $\begin{array}{c}\text { Geomorphologic } \\
\text { feature }\end{array}$ & $\begin{array}{l}\text { Depositional } \\
\text { context }\end{array}$ \\
\hline \multirow{3}{*}{ A } & $\begin{array}{l}\text { WACS-A- } \\
\text { MTB-03 }\end{array}$ & 16 & $\begin{array}{c}06^{\circ} \\
27^{\prime} .26\end{array}$ & $\begin{array}{c}06^{\circ} \\
01^{\prime} .93\end{array}$ & 4884 & levee & \multirow{10}{*}{$\begin{array}{l}\text { Recent lobe } \\
\text { complex }\end{array}$} \\
\hline & $\begin{array}{l}\text { COL-A- } \\
\text { MTB-03 }\end{array}$ & 22 & $\begin{array}{c}06^{\circ} \\
28^{\prime} .21\end{array}$ & $\begin{array}{c}06^{\circ} \\
02^{\prime} .22\end{array}$ & 4764 & & \\
\hline & $\begin{array}{l}\text { COL-A- } \\
\text { MTB-02 }\end{array}$ & 22 & $\begin{array}{c}06^{\circ} \\
27^{\prime} .60\end{array}$ & $\begin{array}{c}06^{\circ} \\
02^{\prime} .08\end{array}$ & 4759 & & \\
\hline $\mathrm{F}$ & $\begin{array}{l}\text { COL-F- } \\
\text { MTB-05 }\end{array}$ & 22 & $\begin{array}{c}06^{\circ} \\
34^{\prime} .83\end{array}$ & $\begin{array}{c}05^{\circ} \\
41^{\prime} .47\end{array}$ & 4864 & levee & \\
\hline \multirow{5}{*}{$\mathrm{C}$} & $\begin{array}{l}\text { WACS-C- } \\
\text { MTB-04 }\end{array}$ & 35 & $\begin{array}{c}06^{\circ} \\
41^{\prime} .26\end{array}$ & $\begin{array}{c}05^{\circ} \\
29^{\prime} .00\end{array}$ & & channel & \\
\hline & $\begin{array}{l}\text { COL-C- } \\
\text { MTB-10 * }\end{array}$ & 19 & $\begin{array}{c}06^{\circ} \\
41^{\prime} .95\end{array}$ & $\begin{array}{c}05^{\circ} \\
29^{\prime} .33\end{array}$ & 4954 & channel & \\
\hline & $\begin{array}{l}\text { COL-C- } \\
\text { MTB-11* }\end{array}$ & 22 & $\begin{array}{c}06^{\circ} \\
41^{\prime} .95\end{array}$ & $\begin{array}{c}05^{\circ} \\
29^{\prime} .33\end{array}$ & 4961 & channel & \\
\hline & $\begin{array}{l}\text { COL-C- } \\
\text { MTB-06 }\end{array}$ & 22 & $\begin{array}{c}06^{\circ} \\
40^{\prime} .27\end{array}$ & $\begin{array}{c}05^{\circ} \\
28^{\circ} .40\end{array}$ & 4951 & levee & \\
\hline & $\begin{array}{l}\text { COL-C- } \\
\text { CS-06 }\end{array}$ & 900 & $\begin{array}{r}06^{\circ} \\
41^{\prime} .95 \\
\end{array}$ & $\begin{array}{c}05^{\circ} \\
29^{\prime} .33 \\
\end{array}$ & 4954 & channel & \\
\hline B & $\begin{array}{l}\text { COL-B- } \\
\text { MTB-12 }\end{array}$ & 22 & $\begin{array}{c}06^{\circ} \\
25^{\prime} .62\end{array}$ & $\begin{array}{c}05^{\circ} \\
49^{\prime} .59 \\
\end{array}$ & 4823 & - & \\
\hline $\mathrm{E}$ & $\begin{array}{l}\text { COL-E- } \\
\text { MTB-14 }\end{array}$ & & $\begin{array}{c}06^{\circ} \\
05^{\prime} .89\end{array}$ & $\begin{array}{c}05^{\circ} \\
54^{\prime} .48\end{array}$ & 4750 & - & $\begin{array}{l}\text { Northern } \\
\text { lobe } \\
\text { complex }\end{array}$ \\
\hline
\end{tabular}


Table 2

\begin{tabular}{|c|c|}
\hline \multirow{2}{*}{$\begin{array}{l}\text { Phytoclasts } \\
\text { (correspond to land plant } \\
\text { debris) }\end{array}$} & opaque - semi opaque fragments - ligneous OM \\
\hline & translucent fragments - cuticles and epidermis \\
\hline \multirow[t]{2}{*}{ Fungal debris } & filamentous particle segmented or not \\
\hline & sclerotia \\
\hline \multirow[t]{2}{*}{ Palynomorphs } & land derived pollen grain and spores \\
\hline & identifiable organic walled algae \\
\hline $\begin{array}{l}\text { Amorphous Organic Matter } \\
(\mathrm{AOM})\end{array}$ & $\begin{array}{l}\text { flaky orange to dark brown-colored organic } \\
\text { components } \\
\text { without visible microscopic structure }\end{array}$ \\
\hline
\end{tabular}


Table 3

\begin{tabular}{|c|c|c|c|c|c|c|c|c|c|c|c|c|c|c|c|c|}
\hline $\begin{array}{l}\mathrm{Si} \\
\text { te }\end{array}$ & Core & & $\begin{array}{l}\text { dian gr } \\
\text { ze }(\mu \mathrm{m}\end{array}$ & ain & & $\mathrm{C}(\%$ & & & $\mathbf{N}$ & & & ${ }^{13} \mathrm{C}($ & & & $\mathbf{N}_{(\mathrm{m}}$ & \\
\hline \multirow{4}{*}{ A } & & $\min$ & $\begin{array}{c}\text { mea } \\
\text { n }\end{array}$ & $\begin{array}{c}\mathbf{m a} \\
\mathbf{x}\end{array}$ & $\begin{array}{c}\mathbf{m i} \\
\mathbf{n}\end{array}$ & $\begin{array}{l}\text { me } \\
\text { an }\end{array}$ & $\begin{array}{l}\mathbf{m} \\
\mathbf{a x}\end{array}$ & $\begin{array}{c}\text { mi } \\
\text { n }\end{array}$ & $\begin{array}{l}\text { me } \\
\text { an }\end{array}$ & $\begin{array}{l}\mathbf{m} \\
\mathbf{a x}\end{array}$ & $\begin{array}{c}\mathbf{m i} \\
\mathbf{n}\end{array}$ & $\begin{array}{l}\text { me } \\
\text { an }\end{array}$ & $\begin{array}{c}\mathbf{m a} \\
\mathbf{x}\end{array}$ & $\begin{array}{c}\mathbf{m i} \\
\mathbf{n}\end{array}$ & $\begin{array}{l}\text { me } \\
\text { an }\end{array}$ & $\begin{array}{l}\mathbf{m} \\
\mathbf{a x}\end{array}$ \\
\hline & $\begin{array}{l}\text { COL-A- } \\
\text { MTB-03 }\end{array}$ & 7.4 & 11.2 & 17.9 & $\begin{array}{l}2 . \\
7\end{array}$ & 3.5 & $\begin{array}{l}3 . \\
8\end{array}$ & $\begin{array}{l}4 . \\
7\end{array}$ & & 6. & 26. & $\begin{array}{c}26 . \\
7\end{array}$ & $\begin{array}{c}- \\
26 . \\
1\end{array}$ & $\begin{array}{l}15 \\
.3\end{array}$ & $\begin{array}{c}17 . \\
9\end{array}$ & $\begin{array}{l}18 \\
.8\end{array}$ \\
\hline & $\begin{array}{l}\text { COL-A- } \\
\text { MTB-02 }\end{array}$ & 7.3 & 11.5 & 22.6 & $\begin{array}{l}2 . \\
7\end{array}$ & 3.4 & $\begin{array}{l}3 . \\
8\end{array}$ & $\begin{array}{l}4 . \\
5\end{array}$ & & $\begin{array}{l}5 . \\
9\end{array}$ & $\begin{array}{c}26 . \\
8\end{array}$ & $\begin{array}{c}- \\
26 . \\
5\end{array}$ & $\begin{array}{c}- \\
25 . \\
7\end{array}$ & $\begin{array}{c}14 \\
.5\end{array}$ & $\begin{array}{c}17 . \\
4\end{array}$ & $\begin{array}{c}19 \\
.9\end{array}$ \\
\hline & $\begin{array}{l}\text { WACS-A- } \\
\text { MTB-03 }\end{array}$ & 7.2 & 10.8 & 22.9 & $\begin{array}{l}2 . \\
2\end{array}$ & 3.0 & . & & & & $\begin{array}{c}26 . \\
5\end{array}$ & $\begin{array}{c}- \\
26 . \\
4\end{array}$ & $\begin{array}{c}- \\
26 . \\
1\end{array}$ & $\begin{array}{c}17 \\
.0\end{array}$ & $\begin{array}{c}19 . \\
0\end{array}$ & $\begin{array}{l}20 \\
.1\end{array}$ \\
\hline$F$ & $\begin{array}{l}\text { COL-F- } \\
\text { MTB-05 }\end{array}$ & 8.2 & 9.2 & 11.3 & $\begin{array}{l}2 . \\
4\end{array}$ & 3.1 & 3. & $\begin{array}{l}5 . \\
0\end{array}$ & 5.3 & $\begin{array}{l}5 . \\
6\end{array}$ & $\begin{array}{c}26 . \\
7\end{array}$ & $\begin{array}{c}26 . \\
3\end{array}$ & $\begin{array}{c}25 . \\
2 . \\
\end{array}$ & $\begin{array}{l}14 \\
.0\end{array}$ & $\begin{array}{c}16 . \\
7\end{array}$ & $\begin{array}{l}18 \\
.5\end{array}$ \\
\hline \multirow[t]{3}{*}{ C } & $\begin{array}{l}\text { COL-C- } \\
\text { MTB-11 }\end{array}$ & $7.2^{*}$ & $9.1^{*}$ & & 3. & 3.9 & $\begin{array}{l}4 . \\
1\end{array}$ & $\begin{array}{l}4 . \\
7\end{array}$ & 5.2 & $\begin{array}{l}5 . \\
9\end{array}$ & $\begin{array}{c}- \\
27 . \\
1\end{array}$ & $\begin{array}{c}- \\
26 . \\
9\end{array}$ & $\begin{array}{c}- \\
26 . \\
5\end{array}$ & $\begin{array}{c}14 \\
.7\end{array}$ & $\begin{array}{c}15 . \\
9\end{array}$ & $\begin{array}{l}17 \\
.1\end{array}$ \\
\hline & $\begin{array}{l}\text { WACS-C- } \\
\text { MTB-04 }\end{array}$ & 8.8 & & & & 3.8 & $\begin{array}{l}5 . \\
0\end{array}$ & - & - & - & $\begin{array}{c}27 . \\
2\end{array}$ & $\begin{array}{c}- \\
26 .\end{array}$ & $\begin{array}{c}- \\
26 . \\
3\end{array}$ & $\begin{array}{l}16 \\
.3\end{array}$ & $\begin{array}{c}18 . \\
9\end{array}$ & $\begin{array}{l}21 \\
.1\end{array}$ \\
\hline & $\begin{array}{l}\text { COL-C- } \\
\text { MTB-06 }\end{array}$ & 6.0 & & 7.6 & $\begin{array}{l}2 . \\
2 .\end{array}$ & 3.3 & $\begin{array}{l}3 . \\
5\end{array}$ & $\begin{array}{l}4 . \\
6\end{array}$ & 5.0 & $\begin{array}{l}5 . \\
3\end{array}$ & $\begin{array}{c}- \\
26 . \\
6\end{array}$ & $\begin{array}{c}- \\
26 . \\
5\end{array}$ & $\begin{array}{c}- \\
26 . \\
1\end{array}$ & $\begin{array}{l}13 \\
.9\end{array}$ & $\begin{array}{c}15 . \\
4\end{array}$ & $\begin{array}{l}15 \\
.8\end{array}$ \\
\hline B & $\begin{array}{l}\text { COL-B- } \\
\text { MTB-12 }\end{array}$ & & 13.9 & 28.8 & $\begin{array}{l}2 . \\
1\end{array}$ & 2.9 & $\begin{array}{l}3 . \\
3\end{array}$ & $\begin{array}{l}4 . \\
7\end{array}$ & 5.2 & $\begin{array}{l}5 . \\
9\end{array}$ & $\begin{array}{c}- \\
26 . \\
5\end{array}$ & $\begin{array}{c}- \\
26 . \\
3\end{array}$ & $\begin{array}{c}- \\
25 . \\
3\end{array}$ & $\begin{array}{l}14 \\
.1\end{array}$ & $\begin{array}{c}18 . \\
5\end{array}$ & $\begin{array}{c}22 \\
.8\end{array}$ \\
\hline E & $\begin{array}{l}\text { COL-E- } \\
\text { MTB-14 }\end{array}$ & 6.2 & 7.2 & 10.6 & $\begin{array}{l}0 . \\
7\end{array}$ & 1.6 & $\begin{array}{l}2 . \\
8\end{array}$ & $\begin{array}{l}6 . \\
3\end{array}$ & 6.8 & $\begin{array}{l}8 . \\
2\end{array}$ & 26. & $\begin{array}{c}- \\
24 . \\
8\end{array}$ & $\begin{array}{c}- \\
22 . \\
8\end{array}$ & $\begin{array}{l}11 \\
.0\end{array}$ & $\begin{array}{c}13 . \\
2\end{array}$ & $\begin{array}{l}15 \\
.9\end{array}$ \\
\hline
\end{tabular}




\section{Highlights}

- Lobe complex and Congo River sediments have similar geochemical characteristics.

- Concentration of soil-derived organic carbon is high in lobe sediments.

- Turbiditic deposition explains the geochemical homogeneity of lobe sediments.

- ${ }^{137} \mathrm{Cs}$ reveals recent and substantial turbiditic deposition in the lobe complex.

- The lobe complex represents a huge sink for terrestrial organic carbon. 